\title{
Characterization of a Highly Biodiverse Floodplain Meadow Using Hyperspectral Remote Sensing within a Plant Functional Trait Framework
}

\author{
Suvarna Punalekar ${ }^{1, *}$, Anne Verhoef ${ }^{1}$, Irina V. Tatarenko ${ }^{2}$, Christiaan van der Tol ${ }^{3}$, \\ David M. J. Macdonald ${ }^{4}$, Benjamin Marchant ${ }^{4}$, France Gerard ${ }^{5}$, Kevin White ${ }^{1}$ \\ and David Gowing ${ }^{2}$ \\ 1 Department of Geography and Environmental Science; School of Archaeology, \\ Geography and Environmental Science, The University of Reading, Whiteknights, PO Box 227, \\ Reading RG6 6AB, UK; a.verhoef@reading.ac.uk (A.V.); k.h.white@reading.ac.uk (K.W.) \\ 2 Department of Environment, Earth and Ecosystems, Open University, Milton Keynes MK7 6AA, UK; \\ irina.tatarenko@open.ac.uk (I.V.T.); David.Gowing@open.ac.uk (D.G.) \\ 3 Department of Water Resources, Faculty of Geo-Information Science and Earth Observation (ITC), \\ University of Twente, Enschede 7500 AE, The Netherlands; c.vandertol@utwente.nl \\ 4 British Geological Survey, Wallingford, Oxfordshire OX10 8BB, UK; dmjm@bgs.ac.uk (D.M.J.M.); \\ benmarch@bgs.ac.uk (B.M.) \\ 5 Centre for Ecology and Hydrology, Wallingford, Oxfordshire OX10 8BB, UK; ffg@ceh.ac.uk \\ * Correspondence: s.m.punalekar@gmail.com; Tel.: +44-0749-752-0550
}

Academic Editors: Clement Atzberger and Prasad S. Thenkabail

Received: 5 December 2015; Accepted: 28 January 2016; Published: 3 February 2016

\begin{abstract}
We assessed the potential for using optical functional types as effective markers to monitor changes in vegetation in floodplain meadows associated with changes in their local environment. Floodplain meadows are challenging ecosystems for monitoring and conservation because of their highly biodiverse nature. Our aim was to understand and explain spectral differences among key members of floodplain meadows and also characterize differences with respect to functional traits. The study was conducted on a typical floodplain meadow in UK (MG4-type, mesotrophic grassland type 4, according to British National Vegetation Classification). We compared two approaches to characterize floodplain communities using field spectroscopy. The first approach was sub-community based, in which we collected spectral signatures for species groupings indicating two distinct eco-hydrological conditions (dry and wet soil indicator species). The other approach was "species-specific", in which we focused on the spectral reflectance of three key species found on the meadow. One herb species is a typical member of the MG4 floodplain meadow community, while the other two species, sedge and rush, represent wetland vegetation. We also monitored vegetation biophysical and functional properties as well as soil nutrients and ground water levels. We found that the vegetation classes representing meadow sub-communities could not be spectrally distinguished from each other, whereas the individual herb species was found to have a distinctly different spectral signature from the sedge and rush species. The spectral differences between these three species could be explained by their observed differences in plant biophysical parameters, as corroborated through radiative transfer model simulations. These parameters, such as leaf area index, leaf dry matter content, leaf water content, and specific leaf area, along with other functional parameters, such as maximum carboxylation capacity and leaf nitrogen content, also helped explain the species' differences in functional dynamics. Groundwater level and soil nitrogen availability, which are important factors governing plant nutrient status, were also found to be significantly different for the herb/wetland species' locations. The study concludes that spectrally distinguishable species, typical for a highly biodiverse site such as a floodplain meadow, could potentially be used as target species to monitor vegetation dynamics under changing environmental conditions.
\end{abstract}


Keywords: MG4 community; field spectroscopy; optical functional types; radiative transfer model; biophysical parameters; sedge and rush

\section{Introduction}

Floodplain meadows are highly biodiverse and sensitive ecosystems supporting numerous species of flora and fauna [1,2]. They also provide a wide range of ecosystem services [3], such as buffer zones during flooding and are an ideal habitat for pollinating insects such as bees. Historically in the British landscape, they were mainly used for hay production and grazing. However, with changes in agricultural policies and also as a result of rapid urbanization, there has been a sharp decline in the area covered by floodplain meadows [4,5]. In particular, the biodiversity of these meadows is under constant threat due to changes in hydrological regime, poor management and agricultural intensification. Because of their high ecological significance, they have been given a high conservation priority, and hence they need to be studied and monitored closely to prevent any further loss of biodiversity.

Being complex ecosystems with delicate interlinkages between vegetation, hydrological and nutrient regimes, floodplain meadows are important sites for studying ecosystem behavior under changing climatic conditions. Although there has been an increase in scientific research on floodplain meadows in recent years, most of the literature is based on time- and labor-intensive conventional methods, such as botanical surveys (for example, [1,2,6]). Integration of these methods with modern technologies can lead to more efficient ways to study and monitor these complex ecosystems. Vegetation spectral data, for instance, provide a promising means to monitor the biodiversity as well as vegetation quality, quantity and dynamics (e.g., [7,8]).

In ecological research, applications of remote sensing data can be grouped into three categories. Firstly, mapping vegetation cover is done by relating vegetation types to spectral data and from that sub-community or species level maps are generated $[9,10]$. Recently, this application has also been extended to mapping biodiversity by correlating spectral variations with species richness or abundance [11,12]. The second category of applications derives empirical relationships between spectral data and vegetation biophysical and biochemical properties such as total biomass, leaf pigments or water content, thereby improving our understanding of the physiological conditions of the vegetation [13-17]. Finally, there are applications that use remotely sensed vegetation properties in ecosystem models to understand functional dynamics such as evapotranspiration and photosynthesis [18-21].

Modern hyperspectral sensors have opened a vast area of research for analyzing species-level differences in biophysical and chemical properties [22-27]. With the availability of fine resolution datasets and advanced knowledge about vegetation and environment interactions, the focus of remote sensing applications in ecological research is gradually shifting towards utilizing spectral data to characterize vegetation into functional types [25,28-31]. This involves integrating all three kinds of applications discussed above, wherein observed spectral differences are explained with respect to biochemical and structural differences in the vegetation and these differences are then related to the functional interactions between vegetation and its environment. Although there is no universally accepted single definition of functional type, it involves "grouping species based on their structural, physiological and/or phenological features in response to environmental conditions or according to their impacts on ecosystem" [29]. Thus, the monitoring of functional types may help predict changes in vegetation with respect to changes in their immediate environment [32-35]. However, the concept of "functional types" is still largely context dependent due to the occurrence of a wide range of physiological, morphological and biochemical traits, which make a discrete classification virtually impossible. Furthermore, multiple approaches exist to classify vegetation into functional types based on ecological, botanical or modeling points of view [29]. Thus, it is important to assess which of these 
functional types are distinguishable in spectral data. From a spectroscopy perspective there are a limited number of useful functional traits such as leaf pigment content, leaf dry matter, water content, Leaf Area Index $(L A I)$, and leaf angle distribution; these all play an important role in radiative transfer and hence govern vegetation spectral behavior $[13,36,37]$. Thus, they can potentially be used to study functional differences in the target ecosystems through spectroscopy $[29,36,38,39]$. This has further led to the concept of "optical functional types", which refers to vegetation functional types that could be traced using spectral datasets $[28,29]$.

Despite these developments, applications to study herbaceous communities are still limited. These communities, in general, are very challenging for spectroscopy research [38] due to the relatively small plant size and the presence of an often diverse assemblage of species and multiple plants in one sampling unit. There have been applications of remote sensing to herbaceous communities, such as those monitoring species diversity (e.g., [32,40-42]) involving retrieval of properties such as $L A I$ and biomass using empirical methods or radiative transfer model inversion [43-46]. However, there is a recognized need for further research on spectroscopy-based vegetation biophysical and functional characterization $[47,48]$.

In this paper, we investigate the potential for and limitations of spectral data in characterizing important optical functional types in a typical UK floodplain meadow community. We assess if it is possible to identify spectrally distinguishable members of the community. We investigate if their leaf and canopy level biophysical and biochemical properties explain the observed differences in vegetation spectra with the help of radiative transfer model. With the help of these properties and some additional functional traits, we explain the functional differences in the optical types. We have also monitored groundwater level and soil available nitrogen to understand differences in the water and nutrient availability in root zone of these optical types. Thus, we assess the potential of optical functional types to be used as effective markers to monitor changes in vegetation in floodplain meadows and associate them with changes in their immediate environment.

\section{Background}

\subsection{MG4 Floodplain Meadows}

In the UK, floodplain meadow communities are described using the National Vegetation Classification (NVC). The meadow used within this study is classified as MG4 [49], which at the European scale forms part of the "Alopecurion alliance" [50]. MG4 is Alopecurus pratensis-Sanguisorba officinalis grassland (syn. Fritillario-Alopecuretum pratensis with 16 constant species referring to those that are typical members of MG4) including grasses and broad leaf herbaceous species. It is one of the most typical floodplain communities in the UK; a semi-natural ecosystem developed as a result of traditional management. This management allows vegetation to grow during spring and summer, which is then cut for hay during June-July, followed by grazing in the two months in early autumn. The hay harvest removes nutrients from the meadows and replacement is primarily via surface water flooding. Nutrient status is then dependent on a combination of groundwater flows, soil-moisture and related soil aeration status, and soil temperature; changes in hydrological regime can significantly alter nutrient availability [1]. The meadow soils often have low nutrient availability, which limits plant growth. This limitation increases the competition between plant species and prevents dominance of the community by any aggressive species, contributing to the high levels of diversity in the plant community [2,49]. This community can consist of many grass and broad leaf herbaceous species as well as several sedges, rushes, ferns and mosses with total numbers of species reaching 40 per square meter. The MG4 community is found on soil that can supply enough water during the growing season and also supports adequate aeration, and is more negatively affected by water logging than by water scarcity [1,2]. On drier soils the MG4 shows transitions towards MG5 community, which has a dominance of dry indicator species such as Centurea nigra and Leucanthemum vulgare; on wetter soils it moves towards MG8 (Cynosurus cristatus-Caltha palustris grassland; [2]) or shows dominance 
of species like Filipendula ulmaria or even wetland species. It is important to note that the NVC system is based on the association of species; it does not directly take into account the soil moisture, nutrient or hydrological conditions. However, extensive research has been carried out to associate the communities with water availability in soil by defining preferred ranges of water table depth through long-term groundwater level (GWL) and botanical surveys [1,2,51].

\subsection{Study Area}

The field site, known as Yarnton Mead, has an area of $32 \mathrm{ha}$, and is located on the floodplain of the River Thames (Figure 1), northwest of the city of Oxford [52] in the lowlands of southern UK (51.791499N, -1.296714E). It forms part of the Oxford Meadows, an EU designated Special Area of Conservation. The site is relatively flat with elevation ranging between 55 and $60.3 \mathrm{~m}$ and has a shallow water table, typically fluctuating within $0.6 \mathrm{~m}$ of the ground surface. Depth to groundwater is determined by a number of factors: proximity to the River Thames, which, due to a downstream weir, has a consistently high water level causing recharge to the gravel aquifer along the whole of its reach adjacent to the meadow; proximity to ditches, primarily the ditch that runs along the north of the meadow, which is both a discharge line and a route for flood waters; but mainly due to the topography, with low-lying zones more prone to waterlogging. The meadow is underlain by alluvial deposits: a fine-grained alluvium of silts, clays and fine-to-medium sand of variable thickness, over calcareous gravel. The predominant soil type is a silty clay loam with an organic top layer of variable thickness. A map of thickness of alluvium was derived for Yarnton Mead from a surface geophysical survey using an EM31ground conductivity meter (Geonics Ltd., Mississauga, ON, Canada). Typical representative species of MG4 and species representing its transition towards MG5 (discussed in Section 2.1) occur mainly in the northwest of the meadow, an area of the field characterized by relatively thin alluvium. Wetness-indicating species are coincident with the low-lying areas and with areas of thick clayey alluvium that have poor drainage (Figure 1). Although alluvium thickness may not directly govern species composition, it plays a role by modulating GWL.

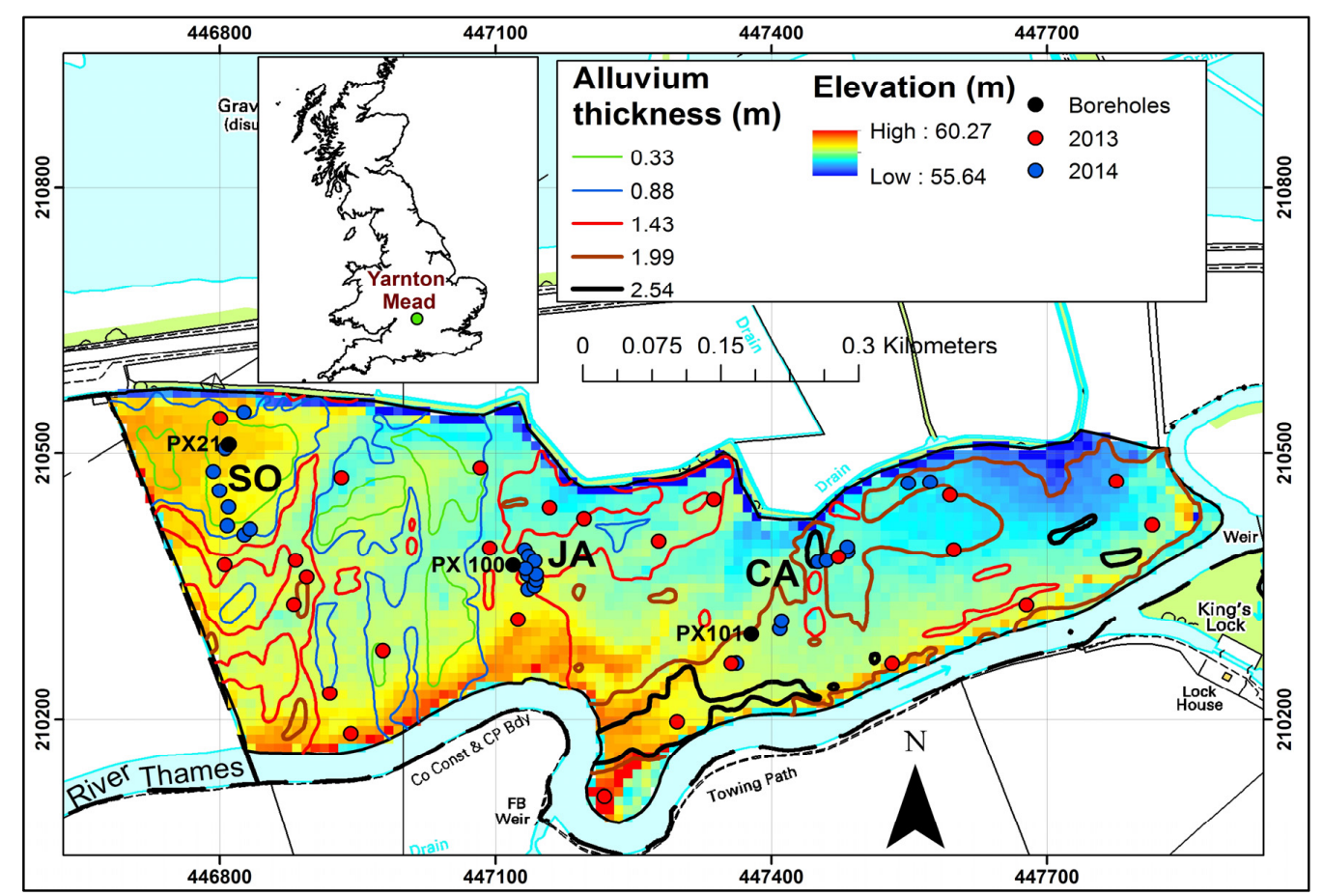

Figure 1. Yarnton Mead with sampling locations for 2013 and 2014, elevation map (from airborne LIDAR survey in June 2014) and alluvium thickness contour lines (Courtesy of Hanson UK), overlaid on Ordnance Survey 1:10,000 scale base-map. 


\section{Materials and Methods}

The field sampling was done during spring and early summer season (end of March to early July) in 2013 and 2014. This period corresponds to undisturbed and rapid vegetation growth, followed by flowering and fruiting stages of the plant life cycle. In 2013, the spectral sampling strategy was designed to capture reflectance of fully-grown species assemblages as their composition changes over the meadow with respect to the soil water availability (i.e., "sub-community based" approach). In 2014, near-homogeneous, fully-grown canopies of three species were targeted for spectral measurements (i.e., "Species based" approach). The observed spectral differences were then explained through vegetation radiative transfer model sensitivity runs and field measurements of plant optical parameters. In addition to the optical parameters, plant functional properties, and nutrient conditions in the plant root zone were studied at species level, with the aim of assessing the functional differences between the typical MG4 representative species and wetland species.

\subsection{Sampling Locations}

For the "sub-community based" sampling in 2013, we considered two subcategories of MG4 based on eco-hydrological differences-DRY and WET. Over the field, 25 locations (Figure 1, red dots) were chosen using a Latin hypercube algorithm [53], which ensured that the variability in elevation, alluvium depth and information from an NVC map [54] was well represented. Although, through the NVC map, overall community level variability was taken into account, exact botanical composition was not known before selection of the sampling locations. Botanical surveys were carried out at these locations in mid May 2013. Based on the projective cover of indicator species in $1 \mathrm{~m}$ by $1 \mathrm{~m}$ sampling plots, the locations were assigned to a DRY or WET category. Table 1 lists species used for the DRY and WET classification. Average score on Ellenberg's moisture scale for DRY species would be 5 and for WET would be 7.4 [55]. In general, the locations with a typical MG4 community, and those showing botanical transition towards MG5 were also grouped into the DRY class, while others with sedges, rushes, and wetness indicating grass and herb species were grouped into the WET class. Furthermore, in addition to the 25 locations, we also included two small transects (one with 14 locations and another with 7 locations, both with roughly $5 \mathrm{~m}$ intervals between adjacent locations) through different vegetation patches. The species assemblages at these locations were also assigned to the DRY or WET classes based on their botanical compositions.

Table 1. List of prominent species, grouped under vegetation classes, studied for spectral discrimination, including the final number of sampling locations (and spectra) after removal of poor-quality measurements.

\begin{tabular}{cccc}
\hline Class & Main Species Found & $\begin{array}{c}\text { Date of } \\
\text { Spectral Sampling }\end{array}$ & $\begin{array}{c}\text { Number of } \\
\text { Sampling Locations }\end{array}$ \\
\hline \multirow{2}{*}{ DRY } & $\begin{array}{c}\text { Sanguisorba officinalis, Centaurea nigra, } \\
\text { Succisa pratensis, Galium verum, Lotus } \\
\text { corniculatus, Primula veris, Dactylis glomerata, } \\
\text { Carex flacca, Festuca rubra, Trisetum flavescens }\end{array}$ & 5 and 9 July 2013 & 25 (400 spectra) \\
\hline \multirow{3}{*}{ WET } & $\begin{array}{c}\text { Carex riparia, Carex acuta, Juncus acutiflorus; } \\
\text { Filipendula ulmaria, Thalictrum flavum, } \\
\text { Lysimachia numullaria, Holcus lanatus, } \\
\text { Hordeum secalinum, Cardamine pratensis, } \\
\text { Agrostis stolonifera }\end{array}$ & 5 and 9 July 2013 & 10 (158 spectra) \\
\hline SO & Sanguisorba officinalis & 12 June 2014 & 8 (131 spectra) \\
\hline CA & Carex acuta, Carex riparia & 13 June 2014 & 10 (146 spectra) \\
\hline$J A$ & Juncus acutiflorus & 12 and 13 June 2014 & 7 (85 spectra) \\
\hline
\end{tabular}

For the species based sampling in 2014, three important species were selected, namely Sanguisorba officinalis (SO), Juncus acutiflorus (JA) and Carex acuta (CA). This choice was based on the following 
important species-differentiating facts: $S O$ is a herb from the Dicotyledonous Class of plants forming rosettes of oblong pinnate leaves and is a typical representative of MG4 community (Figure 2a); JA, a rush, and $C A$, a sedge, represent the Monocotyledon Class of plants differing from the Dicots by their growth habits. Normally they are absent on MG4 meadows or occur in small amounts, however, on Yarnton Mead, they have started to dominate in wet parts of the meadow in recent years [54]. JA has almost cylindrical tube-like, glossy leaves that taper at the end to form a sharp tip (Figure 2c). $C A$, however, has linear, glaucous leaf blades with a bluish tinge (Figure 2b). On Yarnton Mead, $C A$ occurs in close association with another big sedge, Carex riparia; because of their similar growth habit, we grouped them together into $C A$. Besides these botanical observations, the change in spectral sampling, from sub-community to species based approach, was driven also by conclusions drawn from the spectral data analysis obtained in 2013 (discussed in Section 4.1.1).

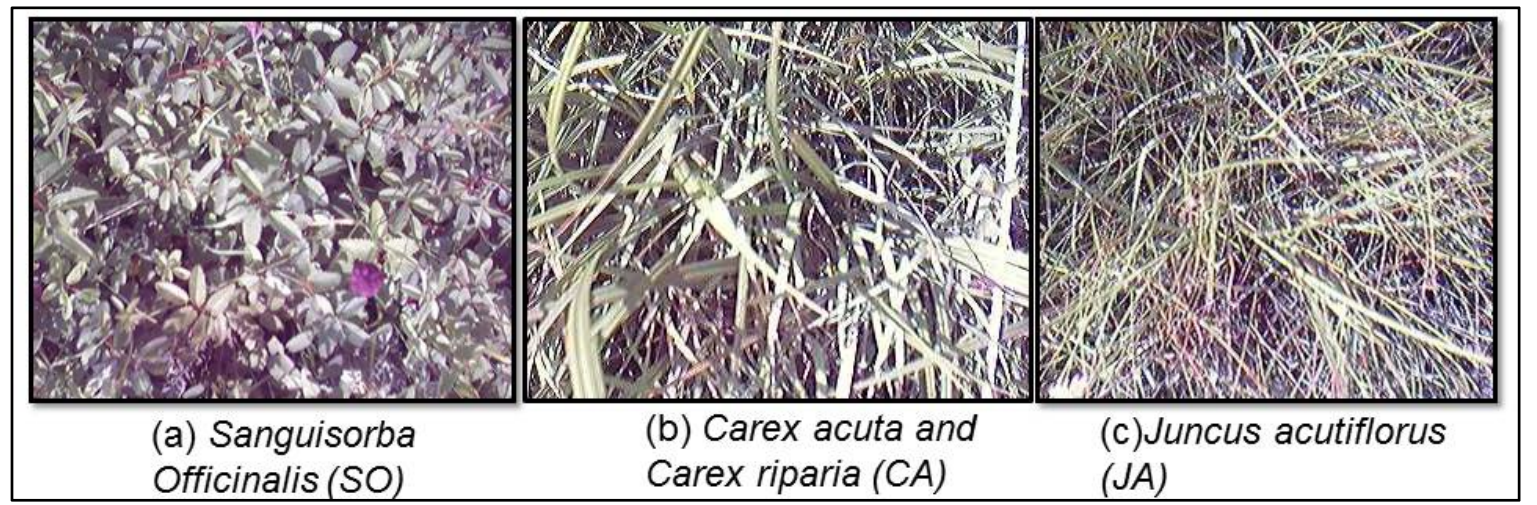

Figure 2. Digital photographs showing top of canopy (1 m height above ground) for (a) Sanguisorba officinalis (SO); (b) Carex acuta and Carex riparia (CA) and (c) Juncus acutiflorus (JA). Photographs taken on 12 and 13 June 2014.

We identified three areas in the field where one of the target species was most abundant (Figure 1). Next, 10-12 locations were chosen in each area based on the criteria that within a $1 \mathrm{~m}$ by $1 \mathrm{~m}$ plot around the location (marked with canes) the projective cover of the target species was more than $90 \%$ (blue dots in Figure 1) and locations are at least $5 \mathrm{~m}$ away from each other.

\subsection{Spectral Sampling, Post Processing and Analysis}

Spectral radiance in nadir direction was measured in 2013 with a SVC HR-1024 hyperspectral spectroradiometer on 5 and 9 July, and in 2014, with a slightly advanced version of the same instrument (known as SVC HR-1024i; with on-board digital camera and GPS) on 12 and 13 June. Both spectroradiometers record the radiance for more than 900 spectral bands covering the visible (VIS), near infrared (NIR) and short wave infrared (SWIR) regions of wavelengths, and have a similar spectral resolution ( $3.5 \mathrm{~nm}$ in VIS, $9.5 \mathrm{~nm}$ in NIR and $6.5 \mathrm{~nm}$ in SWIR). Foreoptics with $8^{\circ}$ instantaneous field of view was used for spectral sampling from $1 \mathrm{~m}$ height above the ground, sampling a circular ground area of $154 \mathrm{~cm}^{2}$ (i.e., a radius of $6.9 \mathrm{~cm}$ ). Each radiance measurement was taken with an integration time of $3 \mathrm{~s}$. At each sampling location a plot of 1 by $1 \mathrm{~m}$ was sampled. It was divided into 16 grid-cells of equal size $(\sim 0.25 \mathrm{~m}$ by $0.25 \mathrm{~m})$. Target measurements were taken approximately in the center of each of these 4 by 4 grid-cell configurations. Regular reference measurements, required to convert radiances into reflectance, was taken over spectralon panel before every 4 target measurements. The same measurement protocol was followed in both years. Sampling dates reflect maximum vegetative growth and predominantly clear sky conditions necessary for spectroscopy. However, not all planned locations could be sampled on each sampling date due to interruptions caused by the frequent and partial cloud cover. 
The radiance data were post-processed to produce calibrated reflectance spectra $\left(\rho_{\lambda} ;\right.$ subscript $\lambda$ refers to wavelength) using the field spectroscopy toolbox (Field Spectroscopy Facility, http://fsf.nerc.ac.uk). This process, followed by qualitative checks using the field photographs and notes, led to further removal of spectral data that were considered sub-optimal due to poor illumination conditions. An average reflectance spectrum for each location was calculated using all good quality spectra at that location (mostly ranging between 10 and 16 in number).

Different tests were performed using the spectral reflectance data to characterize spectral variations between the sub-community and species based vegetation classes. The average and standard deviation of each vegetation class was calculated using all locations within the class.

The discrimination metric $D$ [56] was calculated to assess the dissimilarity in the $\rho_{\lambda}$ measured over the two sub-communities and three key species,

$$
D=\left[\frac{1}{n-1} \sum_{i=1}^{n}\left(\rho_{\lambda_{i}}^{r e f}-\rho_{\lambda_{i}}^{\text {sam }}\right)^{2}\right]^{1 / 2}
$$

where $n$ is the number of wavelengths used between 400 and $2470 \mathrm{~nm}$ ( $n=923$ for year 2014 data, and 935 for year 2013 data); and superscripts "ref" and "sam" refer to reference and sample spectra, respectively. This metric enables the comparison of vegetation class pairs (for example, comparing $S O$ with $C A$ or WET with $D R Y$ ), with one as the reference and the other as the sample spectrum. Smaller values of $D$ indicate less dissimilarity between reference and sample spectra. $D$ was calculated for all possible class pairs (SO-CA, SO-JA, CA-JA, and DRY-WET).

A further technique (developed by Cochrane [56]), "spectral shape filtering", which differentiates vegetation classes based on the overall shape of their spectra, was implemented. It involves normalizing all the measured $\rho_{\lambda}$ (sam and ref) by dividing them by a standard spectrum and evaluating the location of the normalized spectrum of sam relative to the spectral shape space of the standard spectrum. The standard spectrum is the average $\rho_{\lambda}$ of the ref class. The spectral shape space for $r e f$ class is defined by minimum and maximum values at each wavelength, considering all the normalized spectra of ref. If the average normalized spectra for sam fall within the spectral space of ref, it indicates that sam is spectrally inseparable from ref.

Finally, the difference in $\rho_{\lambda}$ was tested for statistical significance at every wavelength between different pairs of classes. The non-parametric ANOVA test (Mann-Whitney $U$ test) was used for this purpose as it does not rely on the assumption of normal distribution of spectral data and compares sample median rather than mean. It has also been used in similar types of spectroscopy based research $[41,57,58]$.

\subsection{Field Data Collection for Vegetation Biophysical and Functional Properties}

The canopy-level structural parameter LAI was measured in 2013 and 2014 using the Sunscan Canopy Analysis System (Delta-T Devices, Burwell, UK). Five to seven measurements were taken below the canopy at every location. LAI was measured within 1 to 5 days of the spectral sampling. Simultaneously with the spectral sampling on 12 and 13 June 2014, leaf samples were collected for each target species to obtain leaf chlorophyll content $\left(L_{c c}\right)$, leaf dry matter content $\left(L_{d m c}\right)$, leaf water content $\left(L_{w c}\right)$ and specific leaf area $(S L A)$, using standard laboratory techniques. Leaf samples from different locations were bulked to form a main sample. Ten leaves were drawn from the main sample for determination of $L_{c c}$. Chlorophyll content was obtained by acetone extraction method, and standard equations $[59,60]$ were used to convert the absorbance measurements into chlorophyll concentrations. Another set of 10 leaves was used to measure leaf area using a calibrated Delta-T leaf area meter. Once the area was measured, leaves were weighed immediately for fresh weight. They were then oven-dried at $80^{\circ} \mathrm{C}$ for 48 hours, and weighed again to determine $L_{d m c}, L_{w c}$ and $S L A$. $L_{c c}, L_{d m c}$ and $L_{w c}$ were expressed in mass per $\mathrm{cm}^{2}$ of leaf area, as required for the radiative transfer model simulations. 
After leaf biochemical analysis, the remaining plant material was dried at $80{ }^{\circ} \mathrm{C}$ for two days, ground into fine powder and subjected to total carbon and nitrogen analysis in a Thermo Flash 2000 Carbon Nitrogen Analyser, using aspartic acid as standard material for calibration. This analysis gave percentage of leaf nitrogen and carbon content $\left(N_{l}\right.$ and $\left.C_{l}\right)$ in leaf dry matter.

Along with the spectral sampling in June 2014, $\mathrm{CO}_{2}$ response curves (also known as $A-C_{i}$, or photosynthesis-intercellular $\mathrm{CO}_{2}$ response curves) were also measured using a LICOR-6400 InfraRed Gas Analyser (IRGA) to estimate $V_{c \max }$ (maximum carboxylation capacity of Rubisco enzyme involved in photosynthesis) for $S O, C A$ and $J A$. The protocol for these measurements was developed based on [61]. Subsequently, leaves used for determination of the response curves were cut, and their area was measured using a leaf area meter. The $A-C_{i}$ curves were corrected for actual leaf area and then used in Curve-Fit GUI (version 0.5) to estimate $V_{\text {cmax }}$ [62].

The vegetation and soil available nitrogen (explained in Section 3.5) have been tested for significant difference among different vegetation groups by one-way ANOVA tests using GENSTAT statistical package (v16.1.10916). When testing more than two groups (for example, SO, CA and JA) for significant difference, Fisher's unprotected $t$-test was used for pair-wise comparison. We inspected the histogram of the residuals and a plot of the expected normal quantiles against the residuals to ensure that the residuals approximated a normal distribution. Single outliers were identified amongst the measurements of dry matter and water content. These were removed prior to conducting the ANOVA.

\subsection{Model Simulations}

A one-by-one sensitivity analysis was conducted with the PROSAIL canopy radiative transfer model $[37,63,64]$ to help explain the effect of each optical parameter on $\rho_{\lambda}$ in association with the field measurements. The PROSAIL model is a coupled canopy (SAIL) and leaf radiative transfer (PROSPECT) model that has been widely used and tested for different kinds of canopies such as agricultural crops, grasslands, and forests [37]. The model simulates canopy $\rho_{\lambda}$ based on information provided about illumination and observation geometry, and vegetation and soil optical properties. The vegetation optical parameters are $L A I, L_{c c}, L_{d m c}, L_{w c}$, leaf thickness parameter $(N)$, and a parameter describing leaf inclination. The leaf inclination is modeled using a leaf inclination distribution function $(L I D F)$. Within this function leaf angles are represented by parameter $L I D F_{a}$ in PROSAIL. The value of $L I D F_{a}$ varies from -1.0 for completely erectophile to 1.0 for completely planophile leaves, but the range from -0.5 to 0.5 covers common leaf inclinations in reality. The sensitivity analysis entailed calculation of canopy $\rho_{\lambda}$ in the nadir direction, for different values of the six canopy optical parameters; one parameter was varied at a time, while the others were kept constant (at representative values of $L A I=5 \mathrm{~m}^{2} \cdot \mathrm{m}^{-2}, L_{d m c}=0.008 \mathrm{~g} \cdot \mathrm{cm}^{-2}, L_{c c}=30 \mu \mathrm{g} \cdot \mathrm{cm}^{-2}, L_{w c}=0.009 \mathrm{~cm}, L I D F_{a}=-0.35$ (unitless), and $N=1.6$ (unitless)). The range of parameter values was determined based on the field data, except for $N$, as it could not be easily measured in absence of leaf level spectral measurements. This parameter refers to internal leaf structure, cell arrangements and intercellular air spaces [64]. Some mixed grassland studies have reported values of $N$ around 1.5 to 1.7. In absence of any field-based information, $N$ was varied uniformly within the wide range reported in the literature (i.e., 1.3 to 2.1). The distribution of other parameters within their respective range were chosen such that they are proportional to the sensitivity of $\rho_{\lambda}$ to that parameter [65].

The vegetation over the meadow was very dense and covered soil completely, thus making soil spectral parameterization less important. A typical spectrum of organic meadow soil has been used to describe soil reflectance.

\subsection{Soil Measurements}

Time-integrated availability of root zone soil nitrate $\left(\mathrm{NO}_{3}^{-}\right)$and ammonium $\left(\mathrm{NH}_{4}^{+}\right)$, hence available soil nitrogen over the study period were measured using Plant Root Simulator (PRS) probes (Western-Agsolutions, Saskatoon, SK, Canada, http:/ / www.westernag.ca). These probes are of two types-anion and cation. They consist of ion exchange resin strips $(\sim 7 \mathrm{~cm}$ long and $\sim 1 \mathrm{~cm}$ wide) 
encased in a firm plastic frame. The total surface area of resin strips is $17.5 \mathrm{~cm}^{2}$, including both sides. They were buried vertically down in the soil so that the resin strips were completely in contact with the soil. In 2014, three locations were chosen in each of the $S O, C A$ and $J A$ sampling locations. At each sampling location, four pairs (anion and cation) of PRS probes were installed. Two batches were used: the first set was installed on 3 May and removed on 1 June 2014; the second batch was deployed on 1 June and removed on 4 July 2014. The probes were transported in sealed plastic bags in a cool-box and, after thorough washing in the laboratory using de-ionized water, were then sent in insulated cool-boxes to the manufacturer for analysis.

\subsection{Groundwater Level Data Acquisition}

In the absence of continuous monitoring of root zone soil moisture, groundwater level data $(G W L)$ were used in the study as a proxy for soil moisture. From the existing network of 17 boreholes on the site, three were identified that coincide with the three species-dominated focus areas. The locations of these boreholes are shown in Figure 1. All three boreholes are completed in the gravel aquifer with 1-metre long screens at their base. Non-vented data loggers (Rugged Troll 100, In-Situ, Fort Collins, $\mathrm{CO}, \mathrm{USA}$ ) installed in the boreholes measure pressure; height of the water column above the logger, and in turn the depth to groundwater, is calculated by combining total pressure with output from a barometric pressure data logger (Rugged BaroTroll, In-Situ), also located on Yarnton Mead. The loggers provide water level measurements on an hourly interval, validated by manual monitoring of water levels on a monthly basis using a water level meter (Soil Instruments, Uckfield, East Sussex, UK).

\section{Results}

\subsection{Spectral Variations}

All spectral analysis tests show that the DRY and WET sub-community based classes are spectrally very similar, while for the species based classes results suggest spectral differences between $S O$ and $C A$ or $J A$ with mixed results for differences between $C A$ and $J A$. The results are elaborated further.

\subsubsection{Sub-Community Based Spectral Discrimination}

The spectral variability plot (Figure 3a) of the sub-community based approach shows that the average $\rho_{\lambda}$ of the DRY class was overall slightly higher than that of the WET class across all wavelengths. However, the plots of the mean $\rho_{\lambda}$ along with standard deviation for the two groups consistently overlapped.

The discrimination metric $D$ was equal to 1.66 for the $D R Y-W E T$ comparison and markedly lower than the $D$ values obtained for the species-based approach (see Section 4.1.2 below), indicating a strong similarity between $\rho_{\lambda}$ of these $D R Y$ and WET classes.

The shape filter analysis plot (Figure $3 b$ ) shows the spectral shape space for $D R Y$, and average spectrum of WET normalized with respect to DRY. The normalized spectrum of WET was well within the upper and lower boundary of spectral shape space for $D R Y$. The shape filter analysis confirms the results of the metric $D$ that $\rho_{\lambda}$ of WET could not be distinguished from $D R Y$ at any wavelength.

Finally, results of the band-wise Mann-Whitney U tests (Figure 3c) also showed that the spectral differences between WET and DRY class were not statistically significant over most of the measured wavelengths, except between: 400 and $541 \mathrm{~nm} ; 666$ and $681 \mathrm{~nm} ; 719$ and $728 \mathrm{~nm}$; and 1165 and $1316 \mathrm{~nm}$. However, in the shape filter plot, no difference was observed at these wavelengths. 


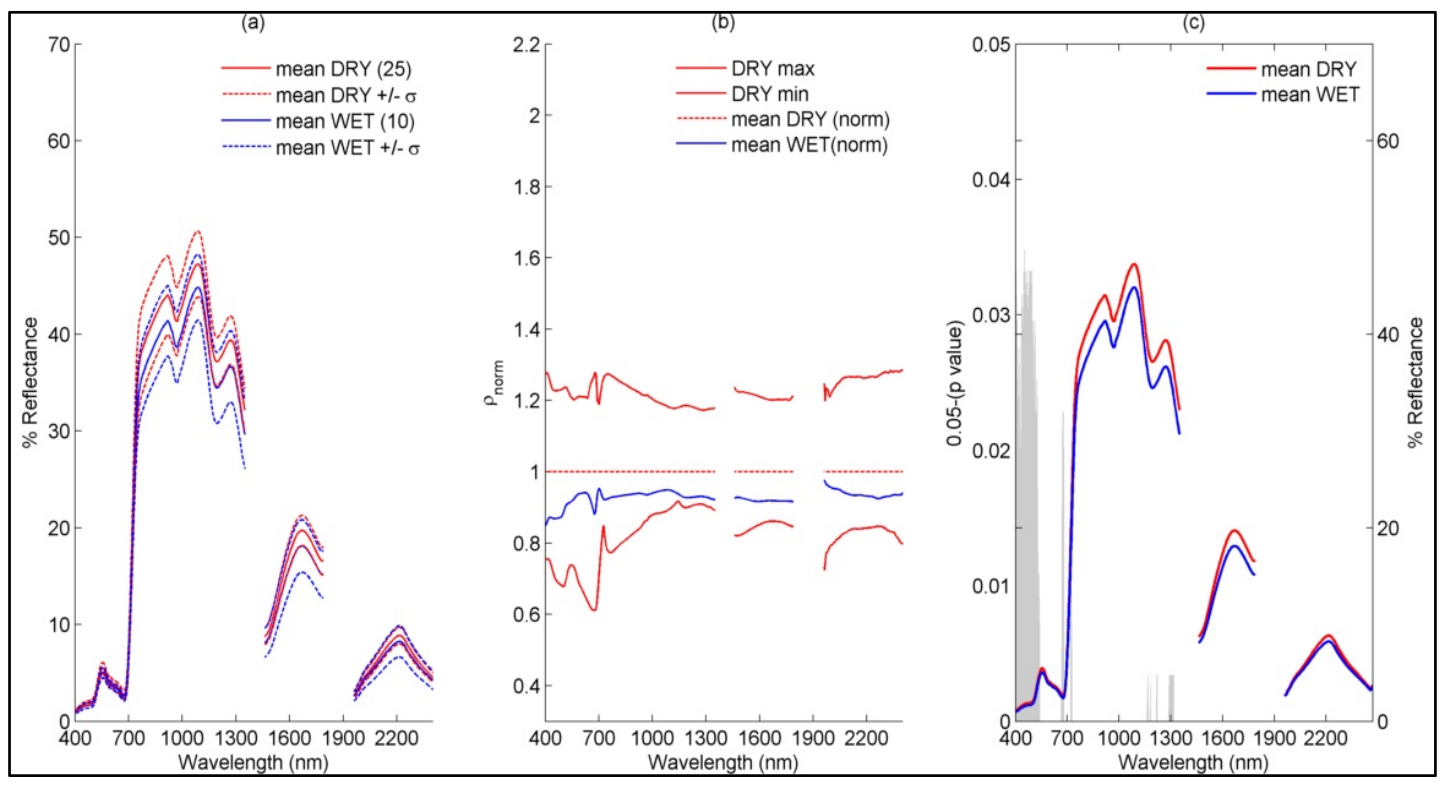

Figure 3. (a) Average spectra (along with standard deviation) measured in nadir direction above canopy of DRY and WET class on 5 and 9 July 2013; (b) Shape filter space of DRY class with mean of normalized (with respect to DRY) spectra of WET class vegetation; (c) Results of wavelength wise Mann-Whitney U test between WET and DRY location spectra showing significant differences in grey scale ( $p$-value $<0.05$ ). Number of sampling locations is given in bracket in the legend of plot $3 a$.

\subsubsection{Species-Based}

Figure 4a shows the average $\rho_{\lambda}$ for $S O, C A$ and $J A$ along with their standard deviations.Reflectance for $S O$ was higher than for $C A$ and $J A$ over almost all wavelengths, but particularly in the NIR and SWIR region (750 to $1200 \mathrm{~nm}$ ). SO had the highest and $J A$ had the lowest $\rho_{\lambda}$, with $\rho_{\lambda}$ for $C A$ located in between. Average $\rho_{\lambda}$ in the NIR shoulder (700 to $750 \mathrm{~nm}$ ) was $50 \%-52 \%$ for $S O, 38 \%-40 \%$ for $C A$ and $30 \%-32 \%$ for $J A$. However, there was considerable overlap between the mean and standard deviation spectra for $J A$ and $C A$ (Figure 4a).

The dissimilarity matrix $D$ was 12.21 between $S O$ and $J A$, and 8.63 between $S O$ and $C A$, which indicates a high dissimilarity between the mean spectrum of $S O$ and those of $C A$ and $J A$. The'dissimilarity matrix $D$ between $C A$ and $J A$ was equal to 3.67 , which is less than the $D$ between $S O$ and $C A$ as well as between $S O$ and $J A$.

The shape filter analysis plot (Figure $4 \mathrm{~b}$ ) shows the spectral shape space for $S O$ and average spectra of $C A$ and $J A$ normalized with respect to $S O$; the $\rho_{\text {norm }}$ of $J A$ could be discerned from $S O$ for all wavelengths. In the case of $C A, \rho_{\text {norm }}$ was outside the spectral shape space of $S O$ for most of the wavelengths, except a few in the $S W I R$ region near $2000 \mathrm{~nm}$. When $J A$ spectra were normalized with respect to $C A$, they also fell outside the spectral shape space of $C A$, but it was aligned much closer to the lower boundary of the shape space of $C A$ in the VIS and NIR part of the spectrum (Figure 4c). The distance between this lower boundary and $\rho_{\text {norm }}$ of $J A$ increased in the SWIR region.

The Mann-Whitney $\mathrm{U}$ tests plots show that $\rho_{\lambda}$ were significantly different between $S O-J A$ and $S O-C A$ over all the wavelengths (Figure $4 \mathrm{~d}$,e). In the case of $C A-J A, \rho_{\lambda}$ was also significantly different over most of the wavelengths, except 15 wavelengths between $1056 \mathrm{~nm}$ and $1110 \mathrm{~nm}$ (Figure 4f). 


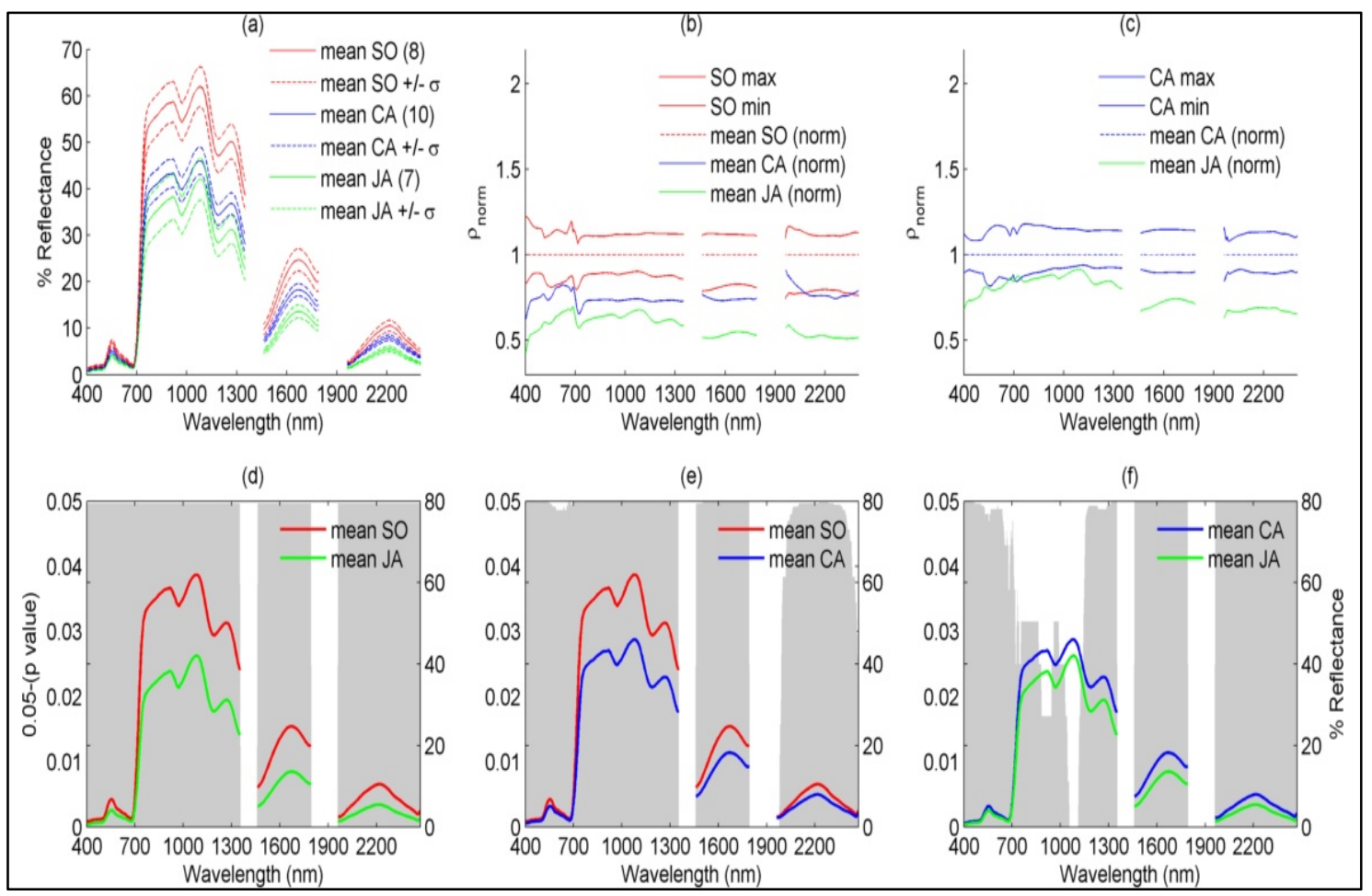

Figure 4. (a) Average spectra (along with standard deviation) measured in nadir direction above canopy of SO,CA and JA on 12 and 13 June 2014; (b) Shape filter space of $S O$ class with mean of normalized spectra (with respect to $S O$ ) of $C A$ and $J A$; (c) Shape filter space of $C A$ class with mean of normalized (with respect to $C A$ ) spectra of $J A$; (d-f) Results of wavelength wise Mann-Whitney $\mathrm{U}$ test between spectra sampled at $S O, C A$ and $J A$ locations spectra. Significant differences are denoted with grey shading ( $p$-value $<0.05)$. Number of sampling locations is given in brackets in the legend of (a).

\subsection{Vegetation Biophysical and Functional Differences}

$L A I$ for $S O$ was generally higher than for $C A$ and $J A$ (Figure 5a) throughout the growing season (also on 13 June 2014, the date of spectral sampling). Multi-date observations of LAI for 2014 show that it increased rapidly between 15 April and 17 May, and more gradually throughout the end of May and early June. The range of $L A I$ values presented in Figure 5a illustrates how dense the vegetation was. Table 2 shows that, as per ANOVA tests (at $5 \%$ level of significance), LAI of $S O$ was always significantly different from $J A$ and $C A$. When comparing the DRY and WET classes, LAI was not statistically significantly different (Figure $5 b, p$-value 0.811 ).

The values for leaf parameters, $L_{d m c}$ and $L_{w c}$, measured for $S O$ were significantly lower than those found for the sedges, $C A$ (Figure $5 \mathrm{~d}$,e and Table 2). Furthermore, mean $L_{d m c}$ and $L_{w c}$ also differed significantly between $C A$ and $J A$ (Table 2). JA had the highest $L_{d m c}$ and $L_{w c}$ among all three species. $S O$ and $C A$ had similar $L_{c c}$ values; significantly higher than those recorded for $J A$ (Figure $5 c$ and Table 2).

Figure 6 shows the other functional properties of SO, JA and CA.SO had higher SLA than CA and $J A$ (Figure 6a), and higher $N_{l}$ and $V_{c \max }$ values (Figure $6 \mathrm{~b}, \mathrm{c}$ ), while $C A$ and $J A$ were indiscernible from each other. Average $N_{l}: C_{l}$ values for $S O, C A$ and $J A$ were $0.054,0.024$ and 0.024 , respectively. ANOVA results reported in Table 2 also show that at the $5 \%$ level, SO had significantly different $S L A, N_{l}, V_{c m a x}$ and $N_{l}: C_{l}$ values compared to $C A$ and $J A$. 


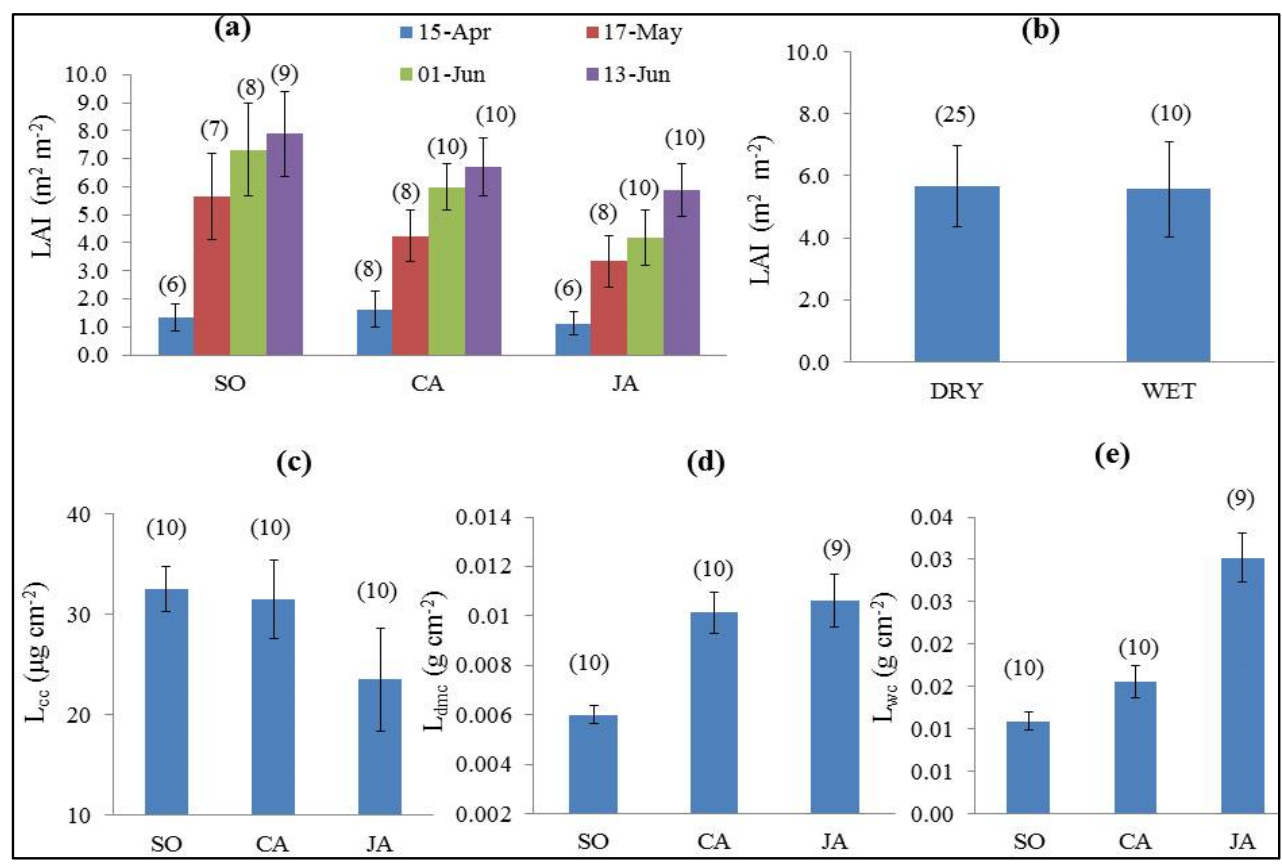

Figure 5. (a-e) Field measurements for (a) $L A I$, (c) leaf chlorophyll content; (d) leaf dry matter content; (e) leaf water thickness for SO,CA and JA (measured on 13 June 2014) and (b) LAI measurements for DRY and WET class (measured on 5 and 9 July 2013). The values in the brackets show the number of sampling locations $(\mathbf{a}, \mathbf{b})$ and number of samples (c-e).

Table 2. One-way ANOVA tests results (with $5 \%$ level of significance) for leaf and canopy parameters, soil-available $\mathrm{NH}_{4}^{+}$and $\mathrm{NO}_{3}^{-}$and groundwater levels (GWL). Bold $p$-values denote significant differences (see Figures 5, 6 and 9; and Sections 4.2 and 4.4 for detailed descriptions).

\begin{tabular}{|c|c|c|c|c|c|}
\hline \multirow[t]{2}{*}{ Parameter (unit) } & \multicolumn{3}{|c|}{ Average (Standard Deviation) } & \multirow[t]{2}{*}{$p$-Value } & \multirow{2}{*}{$\begin{array}{c}\text { Significantly } \\
\text { Different Pairs }\end{array}$} \\
\hline & SO & $C A$ & $J A$ & & \\
\hline$L A I\left(\mathrm{~m}^{2} \cdot \mathrm{m}^{-2}\right) 7$ May 2014 & $5.65(1.55)$ & $4.24(0.93)$ & $3.34(0.93)$ & 0.002 & $S O-C A ; S O-J A$ \\
\hline$L A I\left(\mathrm{~m}^{2} \cdot \mathrm{m}^{-2}\right) 1$ June 2014 & $7.31(1.65)$ & $5.99(0.84)$ & $4.19(0.98)$ & $<0.001$ & SO-JA;SO-CA;JA-CA \\
\hline$L A I\left(\mathrm{~m}^{2} \cdot \mathrm{m}^{-2}\right) 13$ June 2014 & $7.88(1.52)$ & $6.69(1.03)$ & $5.88(0.94)$ & 0.001 & $S O-J A ; S O-C A$ \\
\hline $\begin{array}{c}L_{c c}\left(\mu \mathrm{g} \cdot \mathrm{cm}^{-2}\right)(13 \text { June } \\
\text { 2014-for all leaf parameters) }\end{array}$ & $32.59(2.26)$ & $31.54(3.94)$ & $23.54(5.12)$ & $<0.001$ & $S O-J A ; J A-C A$ \\
\hline$L_{d m c}\left(\mathrm{~g} \cdot \mathrm{cm}^{-2}\right)$ & $0.006(0.0004)$ & $0.010(0.0008)$ & $0.011(0.001)$ & $<0.001$ & $S O-J A ; S O-C A ; J A-C A$ \\
\hline$L_{w c}(\mathrm{~cm})$ & $0.010(0.001)$ & $0.020(0.002)$ & $0.030(0.003)$ & $<0.001$ & SO-JA;SO-CA;JA-CA \\
\hline $\operatorname{SLA}\left(\mathrm{cm}^{2} \cdot \mathrm{g}^{-1}\right)$ & $167.01(10.30)$ & $99.34(8.31)$ & $94.99(9.31)$ & $<0.001$ & SO-JA; SO-CA;JA-CA \\
\hline$V_{c \max }\left(\mu \mathrm{g} \cdot \mathrm{cm}^{-2} \cdot \mathrm{s}^{-1}\right)$ & $64.51(16.53)$ & $39.81(6.53)$ & $42.93(2.20)$ & $<0.001$ & SO-JA; SO-CA \\
\hline$N_{l}(\%)$ & $2.33(0.03)$ & $1.08(0.01)$ & $1.07(0.02)$ & $<0.001$ & $S O-J A ; S O-C A$ \\
\hline$N_{l}: C_{l}$ & $0.054(0.0007)$ & $0.024(0.0005)$ & $0.024(0.0003)$ & $<0.001$ & $S O-J A ; S O-C A$ \\
\hline $\mathrm{NH}_{4}^{+}$(May-June 2014) & $2.39(0.04)$ & $3.90(1.45)$ & $2.63(0.20)$ & 0.142 & none \\
\hline $\mathrm{NO}_{3}^{-}$(May-June 2014) & $7.58(0.23)$ & $4.15(0.66)$ & $3.66(2.56)$ & 0.040 & $S O-J A ; S O-C A$ \\
\hline $\mathrm{NH}_{4}^{+}$(June-July 2014) & $3.35(0.91)$ & $3.70(0.06)$ & $2.86(0.43)$ & 0.403 & none \\
\hline $\mathrm{NO}_{3}^{-}$(June-July 2014) & $6.55(1.39)$ & $6.86(2.74)$ & $4.05(3.44)$ & 0.420 & none \\
\hline GWL & & Time series data & & $<0.001$ & $S O-J A ; S O-C A ; J A-C A$ \\
\hline
\end{tabular}




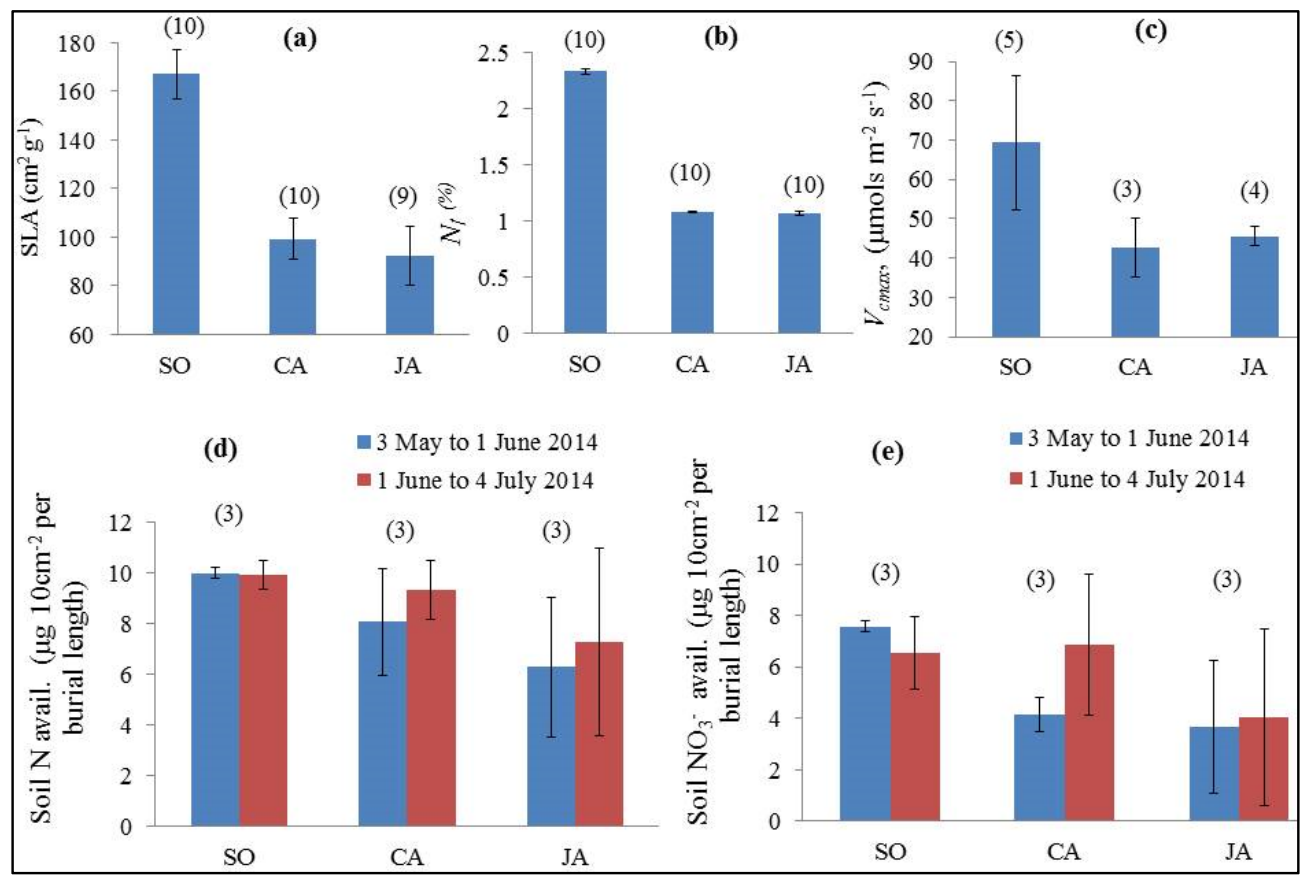

Figure 6. Field measurements for (a) specific leaf area; (b) percentage leaf Nitrogen measured on 13 June 2014; (c) maximum carboxylation capacity measured during May-June 2014 for SO, CA and JA; (d) available soil Nitrogen; and (e) soil available Nitrate in the $S O, C A$ and $J A$ root zone over the burial period. The values in the brackets show number of samples.

\subsection{Radiative Transfer Model Simulations}

The average spectra measured at each location per species $(S O, C A$ and $J A$ ) have been plotted together with PROSAIL model ensemble runs in Figure 7. It shows the suitability of PROSAIL to simulate and help discussion with regards to spectral variability for these target species. The shaded portion represents the model ensemble runs, showing output spectra produced considering all possible combinations of field measured optical parameters for each species. These combinations were produced considering minimum, maximum and average value of each optical parameter as measured on 12 and 13 June 2014. In the case of $L I D F_{a}$, a range from 0 to 0.50 was chosen for $S O$ with an interval of 0.10 (thus covering planophile to uniform leaf inclination types). In the case of $J A$ and $C A$, the range of $L I D F_{a}$ was -0.50 to -0.10 with interval of 0.10 (thus covering erectophile to spherical leaf inclination types). The model shows a good match in the NIR and SWIR region, but relatively poor performance in the VIS region. The model generally overestimates reflectance in the VIS. The model seems to underestimate reflectance in the SWIR wavelengths, especially for wavelengths higher than $2000 \mathrm{~nm}$ (especially for $C A$ and $J A$ ).

Figure 8 shows a sensitivity analysis conducted with the PROSAIL model, for canopy $\rho_{\lambda}$ in the nadir direction, as a function of six model parameters. $L A I$ mainly affects $\rho_{\lambda}$ in the NIR region where $\rho_{\lambda}$ increases with increasing $L A I$ (Figure 8a). Based on the range of $L A I$ chosen, it can be seen that sensitivity of $\rho_{\lambda}$ to $L A I$ reduces progressively towards the higher end of the $L A I$ range. This is also true for the leaf parameters. In the VIS region, $\rho_{\lambda}$ is strongly affected by $L_{c c}$; it decreases with increasing $L_{c c}$, as more light is absorbed by the chlorophyll (Figure 8b). Conversely, $L_{d m c}$ significantly affects the NIR and SWIR region (Figure $8 \mathrm{c}$ ); $\rho_{\lambda}$ decreases with increasing $L_{d m c}$. The effect is more prominent in NIR than SWIR, as in the SWIR part of the spectrum $L_{w c}$ interferes with $L_{d m c}$ due to its strong absorption features (Figure $8 \mathrm{~d}$ ). Reflectance in NIR and SWIR decreases with increasing $L_{w c}$, but most prominently in the water absorption region (around 950, 1200 and $1400 \mathrm{~nm}$ wavelengths; Figure 8d). Another important canopy parameter affecting $\rho_{\lambda}$ in almost all wavelength regions is the leaf inclination angle. 
The canopies with lower $L I D F_{a}$ (nearly vertical leaves) have lower $\rho_{\lambda}$ compared to canopies with higher $L I D F_{a}$ (near planophile), whereas the intermediate values represent intermediate leaf inclination angle distributions such as uniform, oblique and spherical (Figure 8f). The effect of $N$ seems to be less significant in comparison with all other parameters chosen, however it affects all parts of the spectrum equally (Figure 8e).

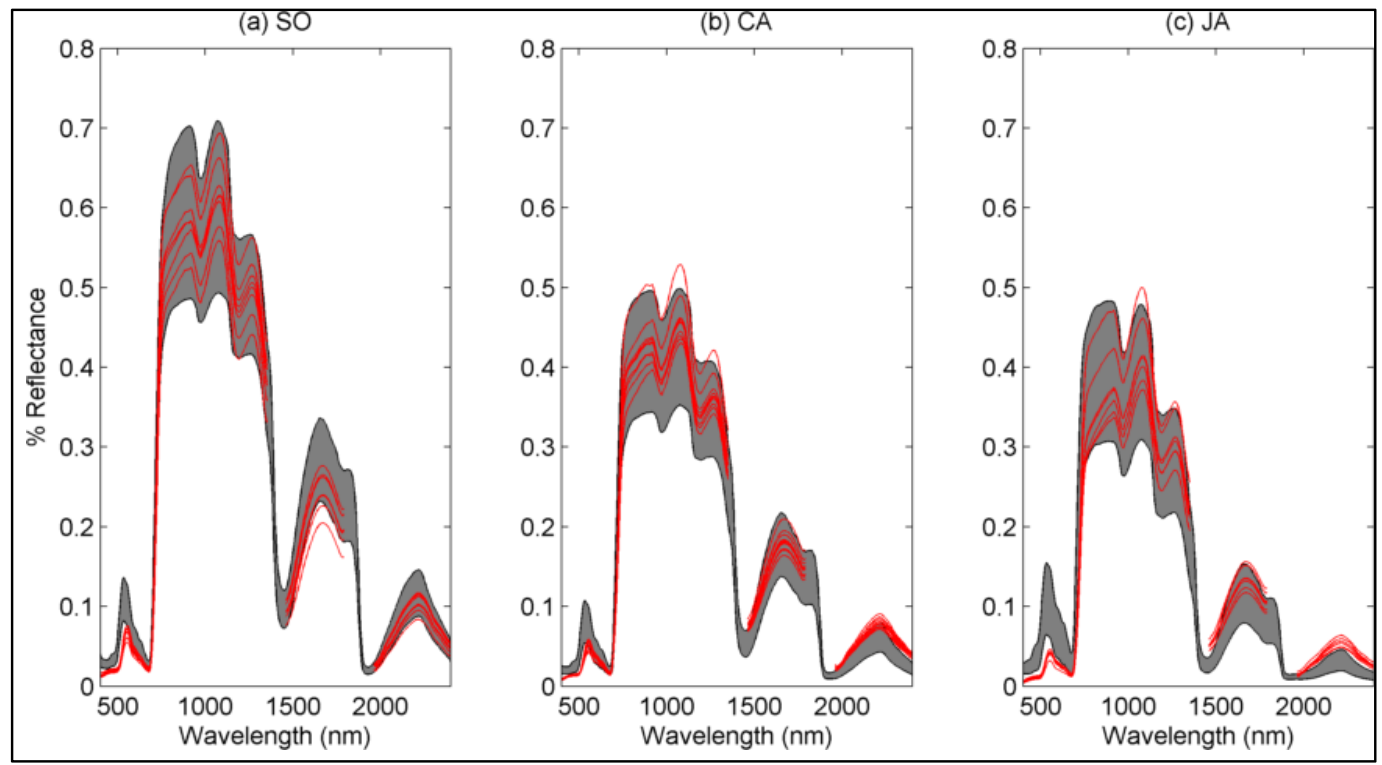

Figure 7. (a-c) PROSAIL model ensemble runs for each target species simulated for every possible combination of leaf and canopy optical parameters. Red lines show average spectra measured on 12 and 13 June 2014 at each sampling location for respective species.

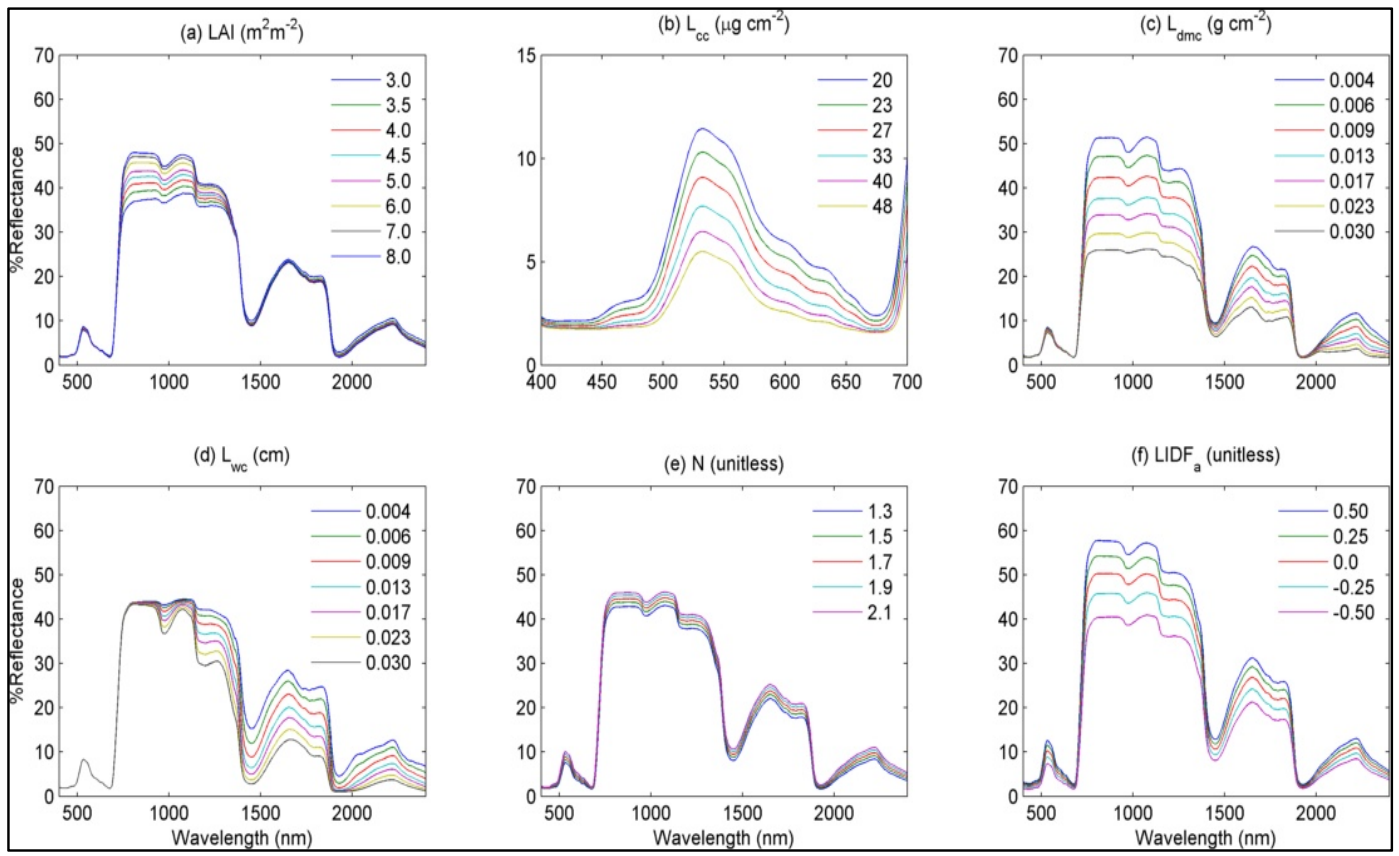

Figure 8. Variations in the spectral reflectance in nadir direction simulated by PROSAIL with respect to changing (a) LAI; (b) leaf chlorophyll content; (c) leaf dry matter content; (d) leaf water content; (e) Leaf thickness parameter; and (f) $L I D F_{a}$. 


\subsection{Soil Nitrogen Availability and Groundwater Level Variations}

Figure 6d,e shows soil nitrogen availability in the root zones of target species during the 2014 study period. Availability of $\mathrm{NH}_{4}^{+}$did not show a significant difference between the different species (Table 2) during either of the burial periods. The availability of $\mathrm{NO}_{3}^{-}$, however, displayed some noticeable differences. Figure $6 \mathrm{~d}$,e shows that in the $\mathrm{SO}$ root zone the availability of soil $\mathrm{NO}_{3}^{-}$(and hence available soil nitrogen) was higher and less variable between the different sampling locations (small error bars). In the case of $C A$ and $J A$, wider error bars show a strongly variable availability across the sampling locations. However, the differences in $\mathrm{NO}_{3}^{-}$between species were only significant for the first burial period (i.e. 3 May to 1 June 2014).

Figure 9 shows daily GWL records for the boreholes in SO (borehole number PX21), JA (PX100) and CA (PX101) dominated parts of the field over the study period (1 March to 15 July 2014). Boreholes near $S O$ locations had deeper GWL than those representing $J A$ and $C A$. The differences in GWL at the three boreholes were statistically significant (Table 2). In the beginning of the season (early March), $G W L$ were very close to the surface in SO-dominant areas and above the surface in the $C A$ - and $J A$-dominant parts. There was an overall recession of GWL during the growing season, superimposed by short-lived rises in GWL, and by the end of June it was approximately $0.7,0.5$ and $0.4 \mathrm{~m}$ below ground level in SO-, CA- and JA-dominated areas, respectively.

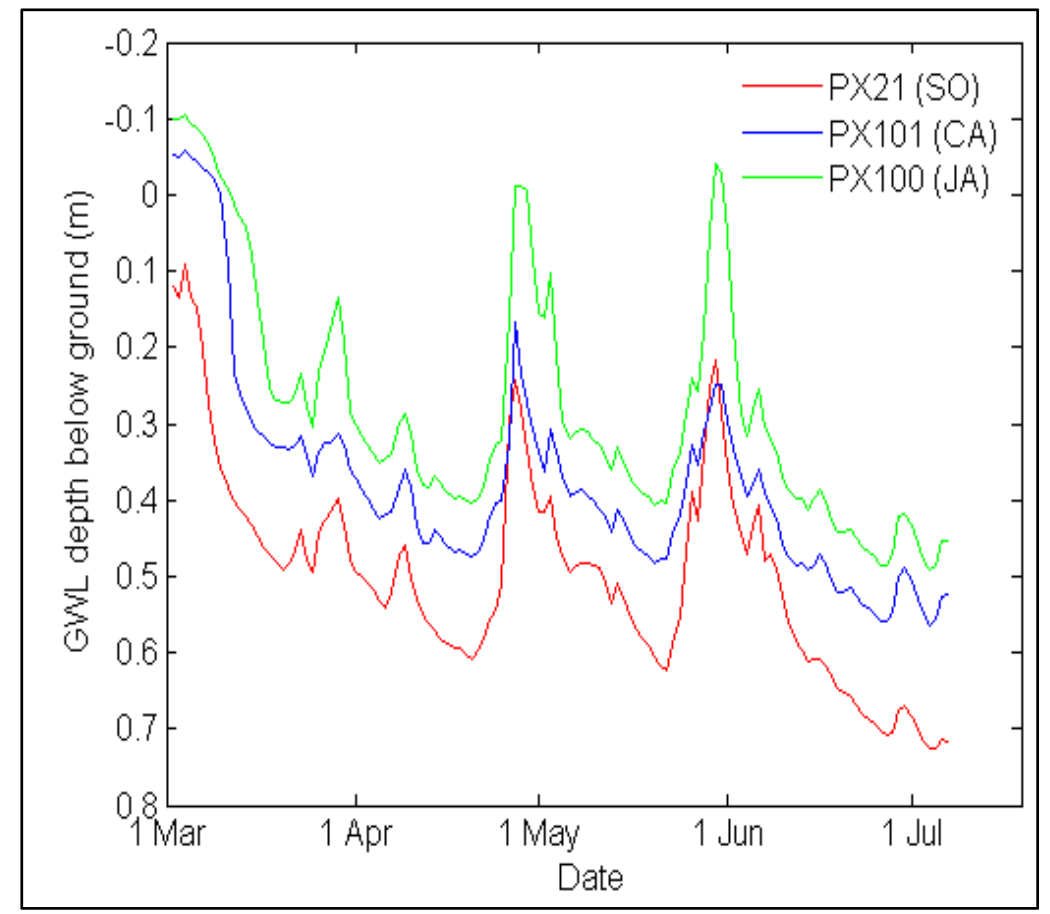

Figure 9. Groundwater levels (from 1 March to 5 July 2014) in boreholes in the SO,CA and JA dominant parts of Yarnton Mead.

\section{Discussion}

\subsection{Explaining Spectral Variability of Meadow Vegetation}

The results in Section 4.1.1 suggest that the two sub-categories of the MG4 vegetation community delineated based on eco-hydrological differences (indicating dry or wet conditions over the field) cannot be distinguished from each other spectrally (Figure 3). For the WET and DRY sub-communities, species class membership was irrespective of their morphological and biochemical differences (for example, Filipendula ulmaria is a broad leaf herb species, which was grouped with $C A$ and $J A$ under WET class) that have been shown to be important in determining $\rho_{\lambda}$. In some locations in $D R Y$ 
sub-community, planophile and wide leaf herbs such as SO and Succisa pratensis were found along with narrow and thick leaf species such as Galium verum and Carex flacca. This kind of species assemblage at the sub-community scale is a result of optimal use of space and resources. Due to this wide variability in life forms and other biophysical and leaf biochemical properties under WET and DRY classes, these sub-communities failed to emerge as spectrally distinct. This argument, however, could be strengthened through more data (other than those gathered for $S O, C A$ and $J A$ ) for optical parameters. These results for DRY and WET community highlight the limitations of using hyperspectral data to distinguish between different sub-communities.

The dependence of $\rho_{\lambda}$ at species level on different optical parameters is illustrated through sensitivity plots (Figures 7 and 8), which concur with results discussed by other researchers [30,36,66,67]. A good match in the NIR and SWIR region illustrates that the model is able to explain the role of different parameters governing $\rho_{\lambda}$ for our target species. The poor match in the VIS region could potentially be due to model representation errors: (1) the model assumes a vertically constant $L_{c c}$, while the upper most leaves in the vegetation, which dominate reflectance measurements, might have an above average $L_{\mathcal{c}}$; or (2) clumping of the vegetation (gaps with lower $L A I)$, which makes it appear darker, especially in the visible domain. The underestimated reflectance in wavelengths higher than $2000 \mathrm{~nm}$ may also be the result of discrepancies between the actual and modeled canopy structure, in particular the distribution of $L_{w c}$ and $L_{d m c}$ within the canopy. Furthermore, for these wavelengths, incoming (and hence reflected) radiation is very low, which makes the spectral measurements more prone to measurement errors.

Among the three species, $S O$, with its planar leaves, had the highest $L A I$ and $L_{\mathcal{c} c}$, and the lowest $L_{d m c}$ and $L_{w c}$. Higher $L A I$ promotes more scattering of light at canopy scale and also enhances expression of leaf optical parameter at canopy scale. However, considering the overall very high $L A I$ values for all three species ( more than $4 \mathrm{~m}^{2} \cdot \mathrm{m}^{-2}$ on 13 June 2014) and reduced sensitivity of reflectance at these higher values (Figure 8a), LAI might not be the dominant factor governing $\rho_{\lambda}$ variability; based on the sensitivity analysis, $L I D F_{a}, L_{d m c}$ and $L_{w c}$ appear more influential factor for $\rho_{\lambda}$. Leaf angles varied from planar for $S O$, to erect for $J A$, which marks the extreme ends of the leaf angle range. Higher sensitivity of $\rho_{\lambda}$, across all wavelengths, to these $L I D F_{a}$ values also helps to explain higher $\rho_{\lambda}$ of SO throughout the spectrum; especially in the VIS, where both SO and CA had higher $\rho_{\lambda}$ than $J A$ despite having higher $L_{\mathcal{C C}}$.

Simulations with PROSAIL for an $L A I$ of $4 \mathrm{~m}^{2} \cdot \mathrm{m}^{-2}$ nevertheless show that the difference in reflectance for a bright (dry) and dark (wet) soil is less than $1 \%$ in the NIR (figure not shown). Thus, soil reflectance cannot explain the differences in reflectance between $S O$ and $C A$.

Although ANOVA tests show that $\rho_{\lambda}$ was significantly different among all species, across almost all the wavelength regions, the variability was more prominent in the NIR, followed by SWIR and then VIS (Figure 4a). A similar pattern was observed by [36] in grass canopies. NIR region in general has proven to be crucial for spectral discrimination among different species in various kinds of ecosystems such as forest, grasslands, marsh, wetlands $[32,41,57,68,69]$. Reflectance in the NIR is mainly due to multiple scattering at leaf and canopy level. Although scattering is not dependent on wavelength, unlike absorption, higher scattering in the NIR is an indirect effect of very low absorption by plants and hence more availability for scattering in this region [30]. At the leaf scale, scattering is dependent on leaf thickness, fraction of intercellular air spaces, and cellular arrangement, while at the canopy scale it is dependent on canopy density (related to $L A I$ and leaf angles). In the PROSPECT model, simulation of leaf level scattering is governed directly by $N$ and indirectly by $L_{d m c}$ and $L_{w c}$. Both $L_{d m c}$ and $L_{w c}$ have weak absorption in the NIR region and strong absorption in theSWIR. The sensitivity analysis shows a decrease in $\rho_{\lambda}$ with increasing $L_{d m c}$ due to more absorption by $L_{d m c}$ as well as less scattering [30,31,70]; this is due to leaves becoming more compact with fewer intercellular spaces. Compared to the SWIR, the effect of $L_{d m c}$ is more significant in the NIR, as it is less affected by absorption by $L_{w c}$ in this region. Our sensitivity analysis shows that $N$ is of less importance at the canopy scale, whereas both $L_{d m c}$ and $L_{w c}$ still appear the dominant factor for $\rho_{\lambda}$. In the case of $S O$, both lower $L_{d m c}$ and $L_{w c}$ values could 
result in more scattering in the NIR and SWIR than would be the case for $C A$ and $J A$. Between $C A$ and $J A$, less variability in $\rho_{\lambda}$ in the NIR could be due to a smaller difference in $L_{d m c}$ and the fact that they have similar leaf angle distributions. Although $L_{w c}$ was significantly different between $C A(0.02 \mathrm{~cm})$ and $J A(0.03 \mathrm{~cm})$, sensitivity of $\rho_{\lambda}$ at those values is reduced (Figure $8 \mathrm{~d}$ ). Thus, the lower $\rho_{\lambda}$ observed in $C A$ and $J A$ compared to $S O$ was the result of a "synergistic effect" of several leaf and canopy level parameters, as discussed in [30].

\subsection{Functional Differences in SO, CA and JA and Optical Parameters as Functional Traits}

It is notable that $L_{d m c}$ (inverse of $S L A$ ), $L_{w c}$ and leaf angles, which emerged in our study as important parameters governing $\rho_{\lambda}$, are also effective indicators of species resource-use strategies [31,34,71]. These parameters along with a few other crucial functional traits such as $N_{l}$ and $N_{l}: C_{l}$ are useful for characterizing the functional dynamics of species [72,73]. Plants with higher SLA tend to have higher $N_{l}$ and higher photosynthetic capacity. This is confirmed by our nutrient analysis and the $V_{c \max }$ values measured. Higher $V_{c \max }$ and $N_{l}$ in $S O$ leaves compared to $C A$ and $J A$ show that $S O$ had a higher photosynthetic capacity. Various researchers have found a correlation between $N_{l}$ and $V_{c \max }$, and also $L_{c c}$, as nitrogen is an important constituent of enzymes used in photosynthesis (e.g., [74,75]). Reich et al. [73] showed that forbs generally have a tendency of accumulating $N_{l}$ and have high $S L A$ and photosynthetic capacity and higher $N_{l}: C_{l}$ ratio. Craine et al. [76] found that plants with lower $N_{l}$ tend to produce sturdy, tough leaves with lower $N_{l}: C_{l}$ ratio, which means higher biomass accumulation per unit $N_{l}$; both $C A$ and $J A$ have thick leaves with more mechanical tissues around their vascular systems. By contrast, $S O$ has loosely arranged mesophyll cells with more intercellular air spaces [77] to support rapid diffusion of $\mathrm{CO}_{2}$ to support higher photosynthesis rates [30]. Greater depth to groundwater below $\mathrm{SO}$ indicates more less mobility of $\mathrm{NO}_{3}^{-}$with soil water and hence higher and more consistent $\mathrm{NO}_{3}^{-}$availability; greater depth to groundwater in this area is a result of higher ground elevation and the closer proximity to the main drainage ditch. In addition, higher photosynthesis in $S O$ is also related to higher transpiration, which is an important factor in root zone drying. Taking into account all functional traits and soil nutrient and water conditions, in the context of basic classification of functional types suggested by [78], $S O$ can be categorized as a competitive plant, adapted to use the available resources in order to maximize carbon gain; whereas $C A$ and $J A$ are more stress-tolerant types that can survive resource-poor conditions due to the lower cost of photosynthesis [79]. The degree of contrast in strategies found within this semi-natural MG4 meadow under given narrow range of variability in soil nutrient and water conditions has been reported in other similar grassland community studies $[33,34,40,79]$.

\subsection{Functional Traits as Ecosystem Monitoring Tool}

The findings of this study support the functional trait-based ecosystem monitoring approach suggested by some researchers $[27,68,76]$. It is evident that sets of functional traits such as $L_{d m c}, L_{w c}$ and leaf angle distribution, indicating a particular type of species resource-use strategy, are also responsible for modulating spectral reflectance of that species; and therefore these traits could be monitored using remote sensing. Ecological monitoring efforts to-date have been largely based on species identification and mapping but in the case of a highly bio-diverse site such as Yarnton Mead, mapping large numbers of species would be a complicated and time-consuming task. Remote sensing-based classification of these kinds of sites may not be always appropriate $[9,10]$, however, the monitoring of functional traits of a few key species at locations within the sites where they dominate could be an effective approach to guide management. Ansquer et al. [68] have shown that monitoring of even two species in grasslands could identify ecosystem response to changes in regulatory factors. The functional trait monitoring could be done through either directly estimating functional traits through empirical or physical models using hyperspectral data, or building databases comprising spectral and functional information of key species. It would involve identification of a small number of key indicator species and regularly obtaining remote sensing data for these species along with some limited in situ data 
about the functional traits. It is important to note that some of these traits, such as $L_{d m c}, L_{w c}$, are easy to study in the field. However, these spectral data-based functional traits monitoring approaches have their own challenges. These involve: establishing the optimal spatial and spectral resolutions for sensing variability in functional traits; improving retrieval efficiency of radiative transfer models' inversion algorithms; and exploring the potential of spectral data in estimating further crucial traits such as $N_{l}, V_{c \max }$. One more important aspect of spectral data-based monitoring is characterization of the temporal changes in the spectral responses of target vegetation. In order to promote spectral based monitoring of similar kinds of vegetation systems, it may be useful to collect data throughout different phenological stages and identify time periods when the discrimination between key species is clearest. Characterizing the spectral changes through time would also be useful to interpret associated changes in vegetation biophysical/chemical properties; for example Chavana-Bryant et al. [80] proposed a statistical model to monitor leaf age and related traits by tracing changes in their reflectance.

Along with the seasonal changes, inter-annual variations in the spectral reflectance, and related interpretations with regards to composition, could be a major concern in some study sites. In our research, the composition of the WET and DRY sub-communities is not expected to change drastically between two consecutive years. Furthermore, in absence of any disturbances such as floods or extensive grazing or manuring efforts, the soil water and nutrient status are not expected to vary dramatically within two years. Hence, considering these facts, we did not expect large differences to occur in the spectral reflectance at the sub-community nor at species level, between the two years. However, other herbaceous communities may have additional challenges due to more dramatic changes in the abiotic factors and related changes in the species composition and vegetation parameters such as leaf water content. In order to deal with all these different issues, regular spectral sampling may be required. However, collecting spectral data (to deal with seasonal and inter-annual variability) under temperate, with related high cloud-cover, conditions prevailing in a country such as the UK is problematic. Spectral data of higher temporal resolution can be obtained by fixed position continuously logging hyper/multispectral sensors, as well as with unmanned aerial vehicles. Thus, in order to advance the application of remote sensing in ecosystem functional dynamics, further research should be directed to respond to these various challenges.

\section{Conclusions}

This study demonstrates the potential of hyperspectral data for functional characterization of key species in floodplain meadow communities. It also supports a functional trait-based monitoring approach for such complex and biodiverse vegetation communities. The study shows that the spectral reflectance of a typical member of MG4 floodplain meadow community, Sanguisorba officinalis, was significantly different $(p$-value $<0.05)$ from the spectra measured on the same meadow for wetland representative species Carex acuta (in association with Carex riparia) and Juncus acutiflorus. Thus, the spectral data, especially at near infrared and short wave infrared wavelengths, can potentially be used to monitor the spread of these wetland species over MG4 floodplain meadows. Furthermore, the spectral differences were explained using field information about optical functional traits in combination with the canopy radiative transfer model. Among these traits, leaf dry matter content, leaf water content and leaf inclination angles were identified as key traits governing spectral response of the meadow vegetation. Along with the optical traits, other vegetation traits such as leaf nitrogen content and maximum carboxylation capacity, as well as soil nitrogen content and groundwater levels were used to explain the functional differences among the spectrally distinct species. This analysis shows that spectral data of a careful selection of a number of key target species can be used effectively to understand the functional diversity in floodplain meadows. However, the study also highlights the limitation of the hyperspectral data in distinguishing sub-communities (e.g., wet versus dry sub-communities) due to the heterogeneous mixture of species.

Further research is needed to study the potential of hyperspectral data and the functional trait based approach to monitor seasonal and inter-annual changes in target species and relate these 
changes with their immediate environment. The major challenge for operational use of this approach for floodplain meadow monitoring would be regular acquisition of good quality hyperspectral data.

Acknowledgments: The research was funded by the Natural Environment Research Council (FUSE project (NE/I007288/1)). Suvarna Punalekar was funded by the Felix trust studentship (F2334465). David Macdonald and Ben Marchant publish with the permission of the Executive Director, British Geological Survey (NERC). We thank Alasdair MacArthur and Christopher MacLellan of NERC Field Spectroscopy Facility, Edinburgh, for their support with hiring field spectroscopy equipment (SVC HR-1024) and Sunscan Canopy Analysis System. We sincerely thank all technical staff and students of the Department of Geography and Environmental Science, University of Reading, who have helped with field data collection and laboratory analyses. We also thank Antonio Diaz Espejo (CSIC, Seville, Spain) for his advice with regards to CO2 response curves. We are very grateful to the Yarnton Mead landowners, Natural England and FAI Farms for allowing us to undertake this study. Funds are available at the University of Reading to cover the cost of publishing this manuscript in open access

Author Contributions: Suvarna Punalekar designed and executed the field experiment and subsequent data analysis and wrote the bulk of the manuscript. Anne Verhoef reviewed the design of the field experiment, guided and helped out with the fieldwork, advised on the data analysis and enhanced the manuscript. Christiaan van der Tol wrote PROSAIL script in MATLAB environment and improved interpretation of model simulations. Irina Tatarenko carried out the species identification and survey and gave a botanical perspective to the sampling strategies. Ben Marchant developed the statistical algorithm used to select the sampling locations for year 2013. $\mathrm{He}$ also contributed to the statistical analysis of spectral data. Kevin White assisted in designing the field spectral sampling design. France Gerard reviewed the manuscript and improved the results interpretation and discussions part. David Macdonald carried out groundwater level data analysis and wrote the relevant sections in the paper on this topic, and David Gowing contributed by providing in-depth knowledge about MG4 meadow ecosystem and also nutrient monitoring using PRS probes.

Conflicts of Interest: The authors declare no conflict of interest. The founding sponsors had no role in the design of the study; in the collection, analyses, or interpretation of data; in the writing of the manuscript; and in the decision to publish the results.

\section{References}

1. Gowing, D.J.G.; Tallowin, J.; Dise, N.; Goodyear, J.; Dodd, M.; Lodge, R. A Review of the Ecology, Hydrology and Nutrient Dynamics of Floodplain Meadows in England; English Nature: Peterborough, UK, 2002.

2. Wheeler, B.D.; Gowing, D.J.G.; Shaw, S.C.; Mountford, J.O.; Money, R.P. Ecohydrological guidelines for lowland wetland plant communities; Brooks, A.E., Jose, P.V., Whiteman, M.I., Eds.; Environmental Agency (Anglian Region): Peterborough, UK, 2004.

3. Posthumus, H.; Rouquette, J.R.; Morris, J.; Gowing, D.J. G.; Hess, T.M. A framework for the assessment of ecosystem goods and services; A case study on lowland floodplains in England. Ecol. Econ. 2010, 69, 1510-1523. [CrossRef]

4. Tockner, K.; Stanford, J.A. Riverine flood plains: Present state and future trends. Environ. Conserv. 2002, 29, 308-330. [CrossRef]

5. Van Diggelen, R.; Middleton, B.; Bakker, J.; Grootjans, A.; Wassen, M. Fens and floodplains of the temperate zone: Present status, threats, conservation and restoration. Appl. Veg. Sci. 2006, 9, 157-162. [CrossRef]

6. Wallace, J.; Verhoef, A. Modelling interactions in mixed-plant communties: Light, water and carbon dioxide. In Leaf Development and Canopy Growth; Marshall, B., Roberts, J.A., Eds.; Sheffield Academic Press: Sheffield, UK, 2000; pp. 204-250.

7. Jones, H.G.; Vaughan, R.A. Remote Sensing of Vegetation: Principles, Techniques and Applications; Oxford University Press: Oxford, UK, 2010.

8. Kerr, J.T.; Ostrovsky, M. From space to species: Ecological applications for remote sensing. Trends Ecol. Evol. 2003, 18, 299-305. [CrossRef]

9. Thomson, A.G.; Fuller, R.M.; Yates, M.G.; Brown, S.L.; Cox, R.; Wadsworth, R.A. The use of airborne remote sensing for extensive mapping of intertidal sediments and saltmarshes in eastern England. Int. J. Remote Sens. 2003, 24, 2717-2737. [CrossRef]

10. Xie, Y.; Sha, Z.; Yu, M. Remote sensing imagery in vegetation mapping: A review. J. Plant Ecol. 2008, 1, 9-23. [CrossRef]

11. Oldeland, J.; Wesuls, D.; Rocchini, D.; Schmidt, M.; Jürgens, N. Does using species abundance data improve estimates of species diversity from remotely sensed spectral heterogeneity? Ecol. Indic. 2010, 10, 390-396. [CrossRef] 
12. Rocchini, D. Effects of spatial and spectral resolution in estimating ecosystem alpha diversity by satellite imagery. Remote Sens. Environ. 2007, 111, 423-434. [CrossRef]

13. Baret, F.; Fourty, T. Estimation of leaf water content and specific leaf weight from reflectance and transmittance measurements. Agronomie 1997, 17, 455-464. [CrossRef]

14. Clevers, J.G.P.W.; Gitelson, A.A. Remote estimation of crop and grass chlorophyll and nitrogen content using red-edge bands on Sentinel-2 and -3. Int. J. Appl. Earth Obs. Geoinf. 2013, 23, 344-351. [CrossRef]

15. Laurent, V.C.E.; Verhoef, W.; Clevers, J.G.P.W.; Schaepman, M.E. Estimating forest variables from top-of-atmosphere radiance satellite measurements using coupled radiative transfer models. Remote Sens. Environ. 2011, 115, 1043-1052. [CrossRef]

16. Zheng, G.; Moskal, L.M. Retrieving leaf area index (LAI) using remote sensing: Theories, methods and sensors. Sensors 2009, 9, 2719-2745. [CrossRef] [PubMed]

17. Marshall, M.; Thenkabail, P. Biomass modeling of four leading world crops using hyperspectral narrowbands in support of HyspIRI mission. Photogramm. Eng. Remote Sens. 2014, 80, 757-772. [CrossRef]

18. Boegh, E.; Thorsen, M.; Butts, M.B.; Hansen, S.; Christiansen, J.S.; Abrahamsen, P.; Hasager, C.B.; Jensen, N.O.; van der Keur, P.; Refsgaard, J.C.; et al. Incorporating remote sensing data in physically based distributed agro-hydrological modelling. J. Hydrol. 2004, 287, 279-299. [CrossRef]

19. Dorigo, W.A.; Zurita-Milla, R.; de Wit, A.J.W.; Brazile, J.; Singh, R.; Schaepman, M.E. A review on reflective remote sensing and data assimilation techniques for enhanced agroecosystem modeling. Int. J. Appl. Earth Obs. Geoinf. 2007, 9, 165-193. [CrossRef]

20. Alfieri, J.G.; Xiao, X.; Niyogi, D.; Pielke Sr, R.A.; Chen, F.; LeMone, M.A. Satellite-based modeling of transpiration from the grasslands in the Southern Great Plains, USA. Glob. Planet. Change 2009, 67, 78-86. [CrossRef]

21. MacBean, N.; Maignan, F.; Peylin, P.; Bacour, C.; Bréon, F.-M.; Ciais, P. Using satellite data to improve the leaf phenology of a global terrestrial biosphere model. Biogeosciences Discuss. 2015, 12, 13311-13373. [CrossRef]

22. Ustin, S.L.; DiPietro, D.; Olmstead, K.; Underwood, E.; Scheer, G.J. Hyperspectral remote sensing for invasive species detection and mapping. IGARSS 2002, 3, 1658-1660.

23. Cho, M.A.; Sobhan, I.; Skidmore, A.K.; Leeuw, J. de Discriminating species using hyperspectral indices at leaf and canopy scales. Remote Sens. Spat. Inf. Sci. 2008, 37, 369-376.

24. Goetz, A.F.H. Three decades of hyperspectral remote sensing of the Earth: A personal view. Remote Sens. Environ. 2009, 113, S5-S16. [CrossRef]

25. Asner, G.P.; Martin, R.E.; Carranza-Jiménez, L.; Sinca, F.; Tupayachi, R.; Anderson, C.B.; Martinez, P. Functional and biological diversity of foliar spectra in tree canopies throughout the Andes to Amazon region. New Phytol. 2014, 204, 127-139. [CrossRef] [PubMed]

26. Marshall, M.; Thenkabail, P. Advantage of hyperspectral EO-1 Hyperion over multispectral IKONOS, GeoEye-1, WorldView-2, Landsat ETM+, and MODIS vegetation indices in crop biomass estimation. ISPRS J. Photogramm. Remote Sens. 2015, 108, 205-218. [CrossRef]

27. Thenkabail, P.S.; Lyon, J.G.; Huete, A. Hyperspectral Remote Sensing of Vegetation; CRC Press-Taylor and Francis group: Boca Raton, FL, USA, London, UK, New York, NY, USA, 2011.

28. Gamon, J.A. Tropical remote sensing-Opportunities and challenges. In Hyperspectral Remote Sening of Tropical and Subtropical Forests; Kalacska, M., Sanchez-Azofiefa, G.A., Eds.; CRC Press Taylor and Francis Group: Boca Raton, FL, USA, 2008; pp. 207-304.

29. Ustin, S.L.; Gamon, J.A. Remote sensing of plant functional types. New Phytol. 2010, 186, 795-816. [CrossRef] [PubMed]

30. Ollinger, S.V. Sources of variability in canopy reflectance and the convergent properties of plants. New Phytol. 2011, 189, 375-394. [CrossRef] [PubMed]

31. Homolová, L.; Malenovský, Z.; Clevers, J.G.P.W.; García-Santos, G.; Schaepman, M.E. Review of optical-based remote sensing for plant trait mapping. Ecol. Complex. 2013, 15, 1-16. [CrossRef]

32. Artigas, F.J.; Yang, J.S. Hyperspectral remote sensing of marsh species and plant vigour gradient in the New Jersey Meadowlands. Int. J. Remote Sens. 2005, 26, 5209-5220. [CrossRef]

33. Kahmen, S.; Poschlod, P. Effects of grassland management on plant functional trait composition. Agric. Ecosyst. Environ. 2008, 128, 137-145. [CrossRef]

34. Rusch, G.M.; Skarpe, C.; Halley, D.J. Plant traits link hypothesis about resource-use and response to herbivory. Basic Appl. Ecol. 2009, 10, 466-474. [CrossRef] 
35. Schellberg, J.; Pontes, L.D.S. Plant functional traits and nutrient gradients on grassland. Grass Forage Sci. 2012, 67, 305-319. [CrossRef]

36. Asner, G.P. Biophysical and biochemical sources of variability in canopy reflectance. Remote Sens. Environ. 1997, 64, 234-253. [CrossRef]

37. Jacquemoud, S.; Verhoef, W.; Baret, F.; Bacour, C.; Zarco-Tejada, P.J.; Asner, G.P.; François, C.; Ustin, S.L. PROSPECT + SAIL models: A review of use for vegetation characterization. Remote Sens. Environ. 2009, 113, S56-S66. [CrossRef]

38. Roelofsen, H.D.; van Bodegom, P.M.; Kooistra, L.; Witte, J.P.M. Trait estimation in herbaceous plant assemblages from in situ canopy spectra. Remote Sens. 2013, 5, 6323-6345. [CrossRef]

39. Roelofsen, H.D.; van Bodegom, P.M.; Kooistra, L.; Witte, J.P.M. Predicting leaf traits of herbaceous species from their spectral characteristics. Ecol. Evol. 2014, 4, 706-719. [CrossRef] [PubMed]

40. Möckel, T.; Dalmayne, J.; Prentice, H.; Eklundh, L.; Purschke, O.; Schmidtlein, S.; Hall, K. Classification of grassland successional stages using airborne hyperspectral imagery. Remote Sens. 2014, 6, 7732-7761. [CrossRef]

41. Schmidt, K.S.; Skidmore, A.K. Spectral discrimination of vegetation types in a coastal wetland. Remote Sens. Environ. 2003, 85, 92-108. [CrossRef]

42. Sha, Z.; Bai, Y.; Xie, Y.; Yu, M.; Zhang, L. Using a hybrid fuzzy classifier (HFC) to map typical grassland vegetation in Xilin River Basin, Inner Mongolia, China. Int. J. Remote Sens. 2008, 29, 2317-2337. [CrossRef]

43. Beeri, O.; Phillips, R.; Hendrickson, J.; Frank, A.B.; Kronberg, S. Estimating forage quantity and quality using aerial hyperspectral imagery for northern mixed-grass prairie. Remote Sens. Environ. 2007, 110, $216-225$. [CrossRef]

44. Li, J.; Liang, T.; Chen, Q. Estimating grassland yields using remote sensing and GIS technologies in China. New Zeal. J. Agric. Res. 1998, 41, 31-38.

45. Darvishzadeh, R.; Skidmore, A.; Schlerf, M.; Atzberger, C. Inversion of a radiative transfer model for estimating vegetation LAI and chlorophyll in a heterogeneous grassland. Remote Sens. Environ. 2008, 112, 2592-2604. [CrossRef]

46. Cayrol, P.; Chehbouni, A.; Kergoat, L.; Dedieu, G.; Mordelet, P.; Nouvellon, Y. Grassland modeling and monitoring with SPOT-4 VEGETATION instrument during the 1997-1999 SALSA experiment. Agric. For. Meteorol. 2000, 105, 91-115. [CrossRef]

47. Adam, E.; Mutanga, O.; Rugege, D. Multispectral and hyperspectral remote sensing for identification and mapping of wetland vegetation: A review. Wetl. Ecol. Manag. 2010, 18, 281-296. [CrossRef]

48. Svoray, T.; Perevolotsky, A.; Atkinson, P.M. Ecological sustainability in rangelands: the contribution of remote sensing. Int. J. Remote Sens. 2013, 34, 6216-6242. [CrossRef]

49. Rodwell, J.S. British Plant Communities. Volume 3. Grasslands and Montane Communities; Cambridge University Press: Cambridge, UK, 1992.

50. Passarge, H. Pflanzengesellschaften des nordostdeutschen Flachlandes, Pflanzensoziologie, 13th ed.; Gustav Fischer Verlag: Jena, Germany, 1964.

51. Araya, Y.; Silvertown, J. A fundamental, ecohydrological basis for niche segregation in plant communities. New Phytol. 2010, 189, 253-258. [CrossRef] [PubMed]

52. Macdonald, D.M.J.; Dixon, A.; Newell, A.; Hallaways, A. Groundwater flooding within an urbanised flood plain. J. Flood Risk Manag. 2012, 5, 68-80. [CrossRef]

53. Minasny, B.; McBratney, A.B. A conditioned Latin hypercube method for sampling in the presence of ancillary information. Comput. Geosci. 2006, 32, 1378-1388. [CrossRef]

54. Wallace, H.L.; Prosser, M.V.; Dodd, M.E.; Sargent, E.; Gowing, D.J.G. Botanical Monitoring (2006-2008) and NVC Survey (2008) of the Oxford Floodplain Meadows; The Floodplain Meadows Partnership: Oxford, UK, 2008.

55. Hill, M.O.; Mountford, J.O.; Roy, D.B.; Bunce, R.G.H. Ellenberg's Indicator Values for British Plants; Institute of Terrestrial Ecology: Huntington, UK, 1999.

56. Cochrane, M.A. Using vegetation reflectance variability for species level classification of hyperspectral data. Int. J. Remote Sens. 2000, 21, 2075-2087. [CrossRef]

57. Clark, M.L.; Roberts, D.A.; Clark, D.B. Hyperspectral discrimination of tropical rain forest tree species at leaf to crown scales. Remote Sens. Environ. 2005, 96, 375-398. [CrossRef]

58. Manevski, K.; Manakos, I.; Petropoulos, G.P.; Kalaitzidis, C. Discrimination of common Mediterranean plant species using field spectroradiometry. Int. J. Appl. Earth Obs. Geoinf. 2011, 13, 922-933. [CrossRef] 
59. Inskeep, W.P.; Bloom, P.R. Extinction coefficients of chlorophyll a and b in n,n-dimethylformamide and $80 \%$ acetone. Plant Physiol. 1985, 77, 483-485. [CrossRef] [PubMed]

60. Zhang, J.; Han, C.; Liu, Z. Absorption spectrum estimating rice chlorophyll Concentration: Preliminary investidation. J. Plant Breed. Crop Sci. 2008, 5, 223-229. [CrossRef]

61. Long, S.P.; Bernacchi, C.J. Gas exchange measurements, what can they tell us about the underlying limitations to photosynthesis? Procedures and sources of error. J. Exp. Bot. 2003, 54, 2393-2401. [CrossRef] [PubMed]

62. Berry, J.A.; van der Tol, C.; Kornfeld, A. A testbed for model development. AGU Fall Meet. Abstr. $2014,1,41$.

63. Verhoef, W. Light scattering by leaf layers with application to canopy reflectance modeling: The SAIL model. Remote Sens. Environ. 1984, 16, 125-141. [CrossRef]

64. Jacquemoud, S.; Baret, F. PROSPECT: A model of leaf optical properties spectra. Remote Sens. Environ. 1990, 34, 75-91. [CrossRef]

65. Weiss, M.; Baret, F.; Myneni, R.B.; Pragnere, A.; Knyazikhin, Y. Investigation of a model inversion technique to estimate canopy biophysical variables from spectral and directional reflectance data. Agronomie 2000, 20, 3-22. [CrossRef]

66. Fourty, T.; Baret, F.; Jacquemoud, S.; Schmuck, G.; Verdebout, J. Leaf optical properties with explicit description of its biochemical composition: Direct and inverse problems. Remote Sens. Environ. 1996, 56, 104-117. [CrossRef]

67. Bowyer, P.; Danson, F.M. Sensitivity of spectral reflectance to variation in live fuel moisture content at leaf and canopy level. Remote Sens. Environ. 2004, 92, 297-308. [CrossRef]

68. Asner, G.P.; Jones, M.O.; Martin, R.E.; Knapp, D.E.; Hughes, R.F. Remote sensing of native and invasive species in Hawaiian forests. Remote Sens. Environ. 2008, 112, 1912-1926. [CrossRef]

69. Adam, E.; Mutanga, O. Spectral discrimination of papyrus vegetation (Cyperus papyrus L.) in swamp wetlands using field spectrometry. ISPRS J. Photogramm. Remote Sens. 2009, 64, 612-620. [CrossRef]

70. Wang, L.; Qu, J.J.; Hao, X.; Hunt, E.R. Estimating dry matter content from spectral reflectance for green leaves of different species. Int. J. Remote Sens. 2011, 32, 7097-7109. [CrossRef]

71. Ansquer, P.; Duru, M.; Theau, J.P.; Cruz, P. Convergence in plant traits between species within grassland communities simplifies their monitoring. Ecol. Indic. 2009, 9, 1020-1029. [CrossRef]

72. Wilson, P.J.; Thompson, K.; Hodgson, J.G. Specific leaf area and dry leaf matter content as alternative predictors of plant strategies. New Phytol. 1999, 143, 155-162. [CrossRef]

73. Reich, P.B.; Ellsworth, D.S.; Walters, M.B. Leaf structure (specific leaf area) modulates photosynthesis-nitrogen relations: Evidence from within and across species and functional groups. Funct. Ecol. 1998, 12, 948-958. [CrossRef]

74. Kattge, J.; Knorr, W.; Raddatz, T.; Wirth, C. Quantifying photosynthetic capacity and its relationship to leaf nitrogen content for global-scale terrestrial biosphere models. Glob. Chang. Biol. 2009, 15, 976-991. [CrossRef]

75. Wohlfahrt, G.; Bahn, M.; Haubner, E.; Horak, I.; Michaeler, W.; Rottmar, K.; Tappeiner, U.; Cernusca, A. Inter-specific variation of the biochemical limitation to photosynthesis and related leaf traits of 30 species from mountain grassland ecosystems under different land use. Plant, Cell Environ. 1999, 22, 1281-1296. [CrossRef]

76. Craine, J.M.; Tilman, D.; Wedin, D.; Reich, P.; Tjoelker, M.; Knops, J. Functional traits, productivity and effects on nitrogen cycling of 33 grassland species. Funct. Ecol. 2002, 16, 563-574. [CrossRef]

77. Sheremetiev, S.N. Meadow Vegetation at the Soil Moisture Gradient; KMK: Moscow, Russia, 2005.

78. Grime, J.P. Evidence for the existence of three primary strategies in plants and its relevance to ecological and evolutionary theory. Am. Nat. 1977, 111, 1169-1194. [CrossRef]

79. Schmidtlein, S.; Feilhauer, H.; Bruelheide, H. Mapping plant strategy types using remote sensing. J. Veg. Sci. 2012, 23, 395-405. [CrossRef]

80. Chavana-Bryant, C.; Malhi, Y.; Jin, W.; Asner, G.; Athanasios, A.; Brian, E.; Scott, S.; Christopher, D.; Roberta, M.; France, G. Leaf aging of Amazonian canopy trees revealed by spectral and physiochemical measurements. New Phytol. 2016. In press.

(C) 2016 by the authors; licensee MDPI, Basel, Switzerland. This article is an open access article distributed under the terms and conditions of the Creative Commons by Attribution (CC-BY) license (http:/ / creativecommons.org/licenses/by/4.0/). 